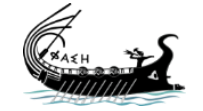

journal.phaselis.org
PHAS KLIS

Issue V (2019)
Disiplinlerarası Akdeniz Araştırmaları Dergisi

Journal of Interdisciplinary Mediterranean Studies

\title{
Hurma Çiftçi Lahdi
}

\section{The Sarcophagus of Farmer from Hurma}

\author{
Ahmet ÇELIK \\ (D) https://orcid.org/0000-0002-7676-0079
}

open access journals

The entire contents of this journal, Phaselis: Journal of Interdisciplinary Mediterranean Studies, is open to users and it is an 'open access' journal. Users are able to read the full texts, to download, to copy, print and distribute without obtaining the permission of the editor and author(s). However, all references to the articles published in the e-journal Phaselis are to indicate through reference the source of the citation from this journal.

Phaselis: Journal of Interdisciplinary Mediterranean Studies is a peer-reviewed journal and the articles which have had their peer reviewing process completed will be published on the web-site (journal.phaselis.org) in the year of the journal's issue (e.g. Issue IV: JanuaryDecember 2018). At the end of December 2018 the year's issue is completed and Issue V: January-December 2019 will begin.

Responsibility for the articles published in this journal remains with the authors.

Citation A. Çelik "Hurma Çiftçi Lahdi". Phaselis V (2019) 231-249. http://dx.doi.org/10.18368/ Pha.19015

Received Date: 22.04.2019 | Acceptance Date: 29.08.2019

Online Publication Date: 24.09.2019

Editing Phaselis Research Project

www.phaselis.org 


\title{
Hurma Çiftçi Lahdi
}

\section{The Sarcophagus of Farmer from Hurma}

\begin{abstract}
Ahmet ÇELIK*
Öz: Antalya Hurma Mahallesi'nde yapılan kazıda bir lahit ve üç ana parça halinde kapağı tespit edilmiştir. Yerel kireçtaşı üzerine oyulan yerel iş̧̧ilikli ve kırsal yaşam konulu lahit, çift sürme sahneli oldukça nadir kompozisyonuyla üniktir. Bazı betimlemeleriyle Pisidia geleneğini yansıtır; Roma İmparatorluk Dönemi içerisinde MS III. yüzyıla tarihlenebilir.
\end{abstract}

Anahtar sözcükler: Hurma, Lahit, Çiftçi, Saban, Öküz, Roma

Abstract: A sarcophagus and three main pieces of lid were found in the excavation in Antalya, Hurma district. The sarcophagus with rural life theme, carved on the local limestone with local craftmanship is unique with its rather rare composition of double plowing scenes. The sarcophagus which reflects the Pisidian tradition with some of its depictions can be dated to the $\mathrm{II}^{\text {rd }}$ centruy AD in Roman Empire period.

Keywords: Hurma, Sarcophagus, Farmer, Plow, Ox, Rome

\section{Giriş}

Antalya İli, Konyaaltı İlçesi, Hurma Mahallesi'nde inşaat yapmak üzere zemin hazırlığı ve hafriyat çalışmaları sırasında bir lahit mezarın ortaya çıktığı bildirilmiş, söz konusu yerde lahit ile üç ana parça halinde kapağının bulunduğu tespit edilmiştir (Fig. 1-3).

Toprakla örtülü olduğu için hatları zorlukla seçilebilen lahdin dıştan etrafının açılmasıyla çalışmalara başlanılmış, ortaya çıkarıldığında; dört yüzüne de iş makinesiyle müdahalede bulunulduğu, üzerinden küçük parçalar koparıldığı, içerisinin boşaltıldığı ve sonra yüzey toprağının içerisine doldurulduğu görülmüştür (Fig. 2, 4). Lahitten çıkarılan toprak, her olasılığa karşı detaylıca incelenmiş ancak kayda değer herhangi arkeolojik bir bulgu tespit edilememiştir ${ }^{1}$.

Antalya Müzesi ön bahçesine taşınıp 2013/181 envanter numarası alan ve podyumuyla birlikte kireçtaşından tek parça bir kayanın işlenmesi ile oluşturulmuş lahdin uzunluğu 2.24 m, genişliği $1.15 \mathrm{~m}$, derinliği ise 0.72 m’dir. Ayrıca yakınında tespit edilen kapak parçaları birleştirilerek lahdin üzerine bırakılmıştır. Kapağın uzunluğu 2.26 m, genişliği 1.22 m, yüksekliği ise 0.69 m'dir (Fig. 5).

\section{Tipoloji}

Lahit teknesinin işlenmiş uzun yüzünün ana sahnesinde bir çift öküzü sabana süren erkek çiftçi kabartması yer almaktadır (Fig. 5). Çiftçi kıvırcık saç ve sakallıdır. Yüzü tam cepheye dönük iken özellikle bacakları 3/4 profil sergiler. Çiftçi sağ elinde sopa tutmaktadır. Üzerinde kasık ile diz

* Dr., Antalya Müzesi Müdür Yardımcısı V., ahmetark.celik@hotmail.com | (D) https://orcid.org/0000-0002-76760079

1 11.09.2013-18.09.2013 tarihleri arasındaki çalışmalar Antalya Müzesi Müdürlüğü’nden Arkeolog Mustafa SAMUR ve Arkeolog Ayşe AKMAN ile birlikte yürütülmüştür, kendilerine teşekkür ederiz. 
arasındaki mesafenin ortasına kadar inen bir tunik bulunur. Tunik kıvrımları dikey çizgilerle belirginleştirilmiş olup olasılıkla kemerle bağlandığından tunik belinde dökümlüdür. Çiftçinin ayağında çizme bulunur ve sol ayağı ile sabana basmaktadır (Fig. 6-8).

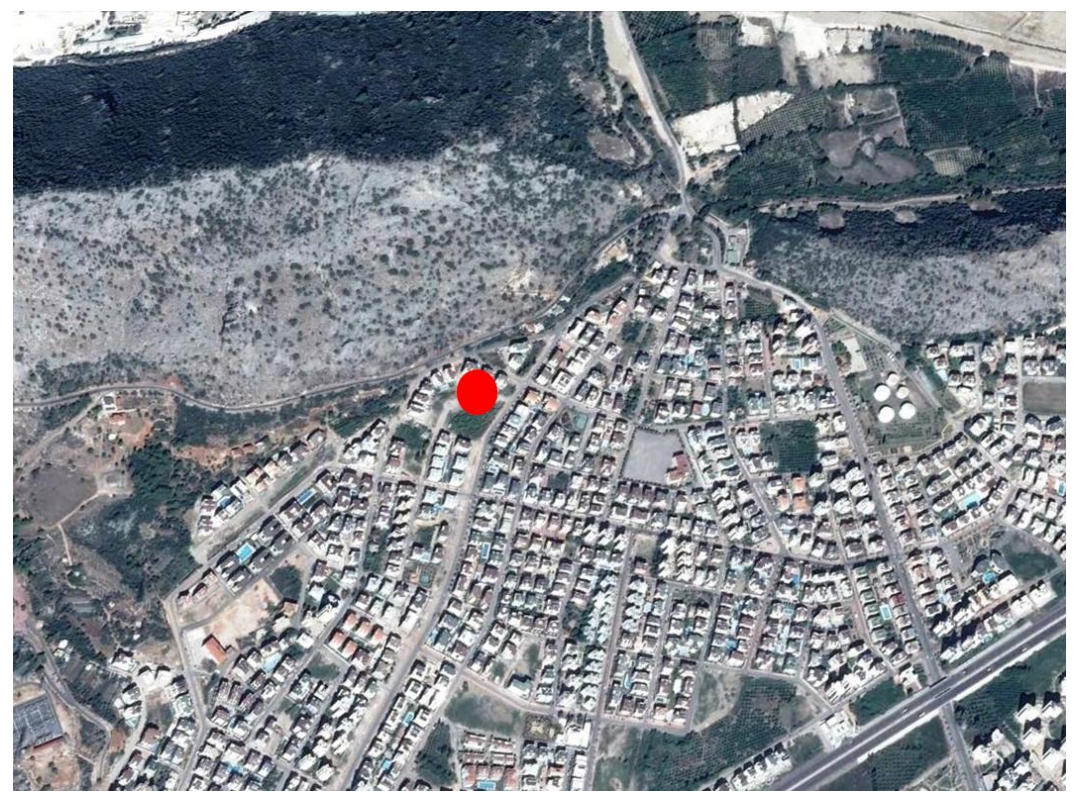

Fig. 1. Hurma Lahdi'nin Bulunduğu Yaklaşık Alan (Google Earth-11.08.2017)

Karşıdan bakıldığında çift sürme sahnesinin üst sağında bulunan çelenk (imago clipeata veya clipeata imago) içerisinde cepheden verilmiş bir erkek büstü bulunur (Fig. 4-5, 9). Buradaki erkek yine kıvırcık saçlıdır, ancak sakal bulunmaz, dolayısıyla genç bir görünüm sergiler. Üst soldaki çelenk içerisinde ise bu kez başında şal bulunan kadın büstü görülür (Fig. 10). Kadının yüzünün sol tarafı kırıldığından belirsizken sol gözünün olduğu kısım ile saçları seçilebilmektedir. Göğsünün merkezinde yatay paralel kavisler ile elbise kıvrımları gösterilmeye çalışılmıştır. Ayrıca her iki büstün çevresindeki çelenk (imago clipeata veya clipeata imago) olasılıkla dairesel biçimlendirilen ikili bitki dalının yatay kuşaklar ile bağlanması ile oluşturulan stilize bir çelenk görünümündedir (Fig. 9-10).

Hurma Lahdi'nin her iki kısa yüzünde ise üzerinde rozet bulunan birer kalkan ve altında birer mızrak yer alır (Fig. 11-12). Lahde karşıdan bakıldığında sağ tarafta kalan kısa yüzdeki kalkanın iç içe iki dairesel kısımdan oluştuğu, içteki dairesel aksamın merkezine dört geniş yapraklı bir rozetin işlendiği görülmektedir. Kalkanın altındaki mızrağın uç kısmı ise 45 derecelik bir açı ile lahdin üst kısmına denk gelecek biçimde konumlandırılmıştır (Fig. 11). Sol kısa yüzdeki kalkan yine iç içe iki dairesel kısımdan oluşmaktadır. Bu kalkanın merkezine altı ince yapraklı bir rozet işlenmiştir. Altındaki mızrağın uç kısmı ise yine 45 derecelik bir açı ile lahdin üst kısmına denk gelecek biçimde konumlandırılmıştır (Fig. 12).

Lahdin arka uzun yüzü kabaca tıraşlanmış ve üzerine herhangi bir figür ya da motif işlenmemiştir (Fig. 13). Lahit podyumunun bir bölümü kabaca işlenmiş olup diğer bölümleri doğal bırakılmıştır. Lahdin podyumunda ve teknesinin bir bölümünde doğal yolla kırılmalar ve çatlamalar tespit edilmiştir (Fig. 4-5, 11-13).

Parçaları birleştirilerek lahdin üzerine bırakılan kapağın ön yüz merkezi kısmında yazısız bir tabula bulunmaktadır (Fig. 14). Arka uzun yüz tarafında kapağın üzeri boş bırakılmıştır (Fig 13). Ayrıca kapağın tepe ve köşe akroterlerinin yalnızca genel hatları oluşturulmuş, başkaca herhangi bir bezeme veya figür işlenmemiştir (Fig. 5, 11-13). 


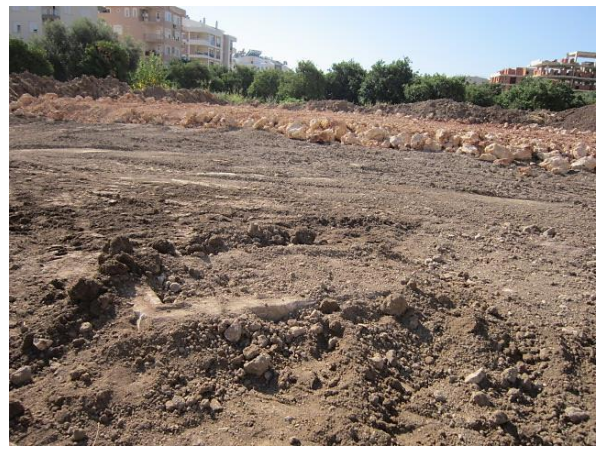

Fig. 2. Kazı Öncesi Lahit

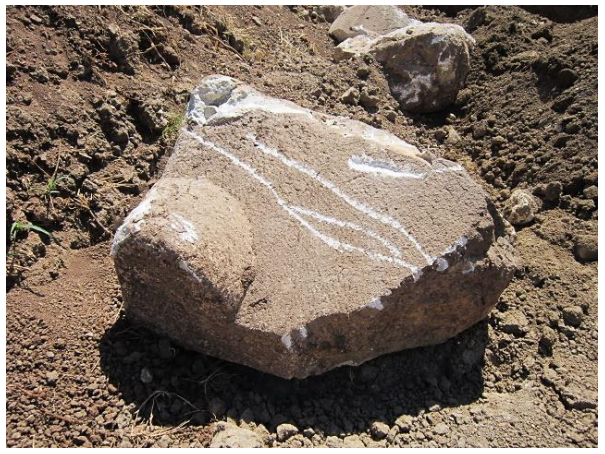

Fig. 3. Lahit Kapağı Parçaları

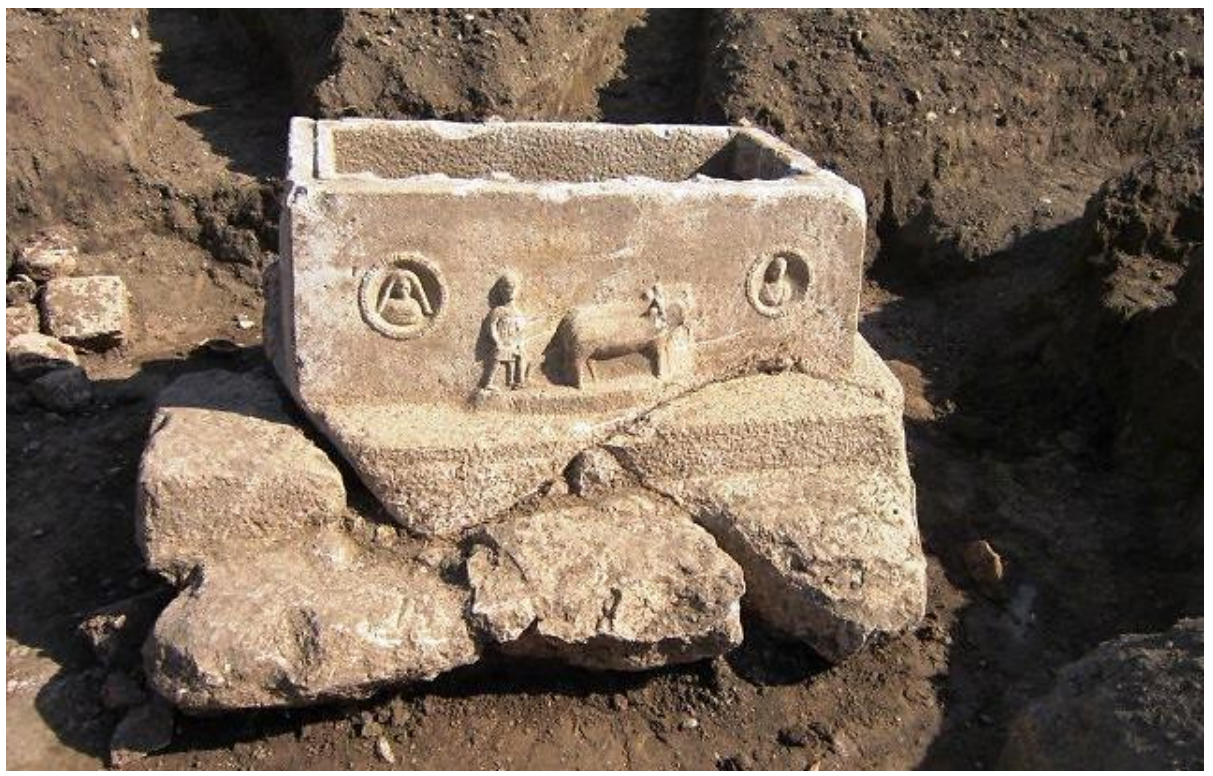

Fig. 4. Kazı Sonrası Lahdin Genel Görünümü

Hurma Lahdi kapağının kısa yüzlerinin her iki alınlığında ise birer Medusa başı bulunur. Lahde karşıdan bakıldığında sağ tarafta kalan kısa yüzün üst kısmına denk gelen kapağın alınlık kısmındaki Medusa'nın yüzünde yıpranmalar bulunmakla birlikte donuk ifade algılanabilmektedir. Mitolojide yılan saçlı olduğu belirtilen Medusa'nın birbirine paralel giden hafif dalgalı saçları burada perçemler halinde verilmiştir. Ayrıca iki taraftaki saçlarından uzatılan birer tutam boynun merkezi alt kısmında fiyonk benzeri bağlanarak bırakılmıştır (Fig. 11). Kapağın sol alınlık kısmındaki Medusa'nın ise yüzünde yine yıpranmalar bulunmakla birlikte donuk ifade burada da algılanabilmektedir. Benzer şekilde Medusa'nın birbirine paralel giden hafif dalgalı saçları perçemler halinde verilmiştir ve iki taraftaki saçlarından uzatılan birer tutam boynun merkezi alt kısmında fiyonk benzeri bağlanarak tutturulmuştur (Fig. 12).

\section{Genel Değerlendirme ve Tartışma}

Neolitik Dönem, insanlığın yerleşik düzene geçip tarım yapmaya başladığı önemli bir dönüm noktasıdır². Bu dönemde öncelikle insan gücüyle sürülen basit sabanlar kullanmıştır; sonra boğa veya öküzün çift sürmede kullanılmasıyla daha fazla ürün elde edilmiş olmalıdır³.

\footnotetext{
Özdoğan 2007, 9 vd.; Işık 2009, 24-26; Kızıltan 2013, 10.
}

3 Illk tarım deneyimi olasılıkla, öncelikle tohumların doğrudan toprağa atılması şeklinde olmuşken daha sonra insan gücüyle çift sürülerek tohumların toprağa atıldığı anlaşımaktadır. Toprağı sürme işlemi için muhtemelen ağaç dallarından kesilen ve sürüldüğünde toprağı etkili kazıyabilen "V" biçiminde sabanlar kullanılmış olmalıdır. Sabanla 
Anadolu'da Kalkolitik Dönem ve Tunç Çağı'nda maden kullanımının artmasıyla önemli gelişmeler sağlanmış; ilkinde bazı tarım aletleri bakırdan imal edilmişken, diğerinde tunç sabanlar yapılmışıı ${ }^{4}$. Geç Kalkolitik Çağı, bölgesinde en iyi şekilde temsil eden Malatya Aslantepe'de MÖ 3300-3000 yılları arasına tarihlenen tapınak-saray yapısının geçenek duvarına, toprağın sürüşünün ilk resmi olarak öküzü karasabana koşan ve sol elinde üvendire tutan bir çiftçi resmedilmiştir. Burada karşılıklı duran bir çift öküzün arasında buğday başağı bulunmaktadır (Fig. 15) . $^{5}$

Görülüyor ki tarım, iklimi, akarsuları ve münbit ovalarıyla Anadolu yaşamının merkezindedir. MÖ II. binyılda Hitit tabletlerinde saban ve sabana koşulan öküzlerden söz edilir ve saban öküzleri satılabildiği gibi aynı zamanda da kiralanabilmektedir ${ }^{6}$. Anadolu'nun I. binyıl devletleri olan Frig, Urartu ve Lidya'da da tarım faaliyetleri çok önemlidir ${ }^{7}$. Bu nedenle saban ve sabana koşulan öküzler önemini korumuş olmalıdır. Ayrıca antikçağda da doğal olarak saban kullanımı devam etmiştir 8 .

Belirtildiği üzere Hurma lahit teknesinin işlenmiş uzun yüzünün ana sahnesinde sağ elinde bir tür sopa yani üvendire ${ }^{9}$, sol eli ile saban/pulluk ${ }^{10}$ tutan ve önünde orantısız verilen hörgüçlü bir çift öküz (Zebu veya Zebus) ${ }^{11}$ bulunan erkek çiftçi kabartması yer almaktadır (Fig. 4-8, 22).

toprak sürülünce toprakta mineral artışı ve sonucunda daha yüksek ürün verimi sağlanmıştır. Boğanın/Öküzün ehlileştirilerek onun gücünün çift sürmede kullanılmasıyla insan gücüyle sürülen basit sabana nazaran daha derin sürülen ve mineral açııından daha zenginleşen topraktan daha fazla ürün alınmış ve bu çift hayvanları tarımsal yaşamda önemli bir yer kazanmışlardır. Bk. Akın - Esgici 2015, 34.

4 Ayrıca, Anadolu'da Kalkolitik Dönem MÖ 6000/5500 ile 3500/3200 arasına, Tunç Çağı MÖ 3500/3200 ile 1200 arasına tarihlenebilir. Bk. Akın - Esgici 2015, 35; Kızıltan 2013, 10-11.

5 Işık 2009, 31; Bununla beraber sadece Anadolu'da tarım, yaşamın merkezinde değildir. Örneğin Nil Nehri'nin suladığı bereketli topraklarda tarımı yoğun bir şekilde yapan Eski Mısır'da daha sonra duvar resim sanatının oldukça güzel örnekleri verilmiş, tarımsal faaliyetlere ilişkin sabanın bir çift öküzle kullanımı benzer şekilde adeta simgesel bir motif olarak tercih edilmiştir. Örnekler için bk. İnan 1956, 64 vd., res. 50, 57; Janic 2002, 24-30, res. 4-D; Rehkugler 2011, 5-6; Ayrıca İtalya'nın kuzey kesiminde kalan Lavagnone'de MÖ 1900-1800 arasına tarihlenen, meşe ağacından yapıldığı anlaşılan ve korunmuş durumda tespit edilen bir saban örneği bu bölge için de tarımın önemini belgelemektedir. Bk. Perini 1984, 362; Perego 2017, 141, 166.

6 Hititler'de 1 şekel 12,4 gram'dır. Saban öküzünün fiyatı 5 şekel gümüş ve/veya 12 şekel gümüştür. Bir saban öküzünün bir aylık kirası 1 şekel gümüştür. Reyhan 2010, 66-75; Ayrıca bk. Hoffner 2010, 230.

Bülbül 2017, 276-280.

8 Örneğin, MÖ 530'a tarihlenen ve Nikosthenes ressamına ait siyah figür tekniğinde bir kylix tondosunda çekirge gibi tarım zararlısı ile mücadelenin yanı sıra bir çiftçinin iki boğayı sabana koşması resmedilmiştir. Gow 1914, 252, fig. 3; Ayrıca Klasik Dönem içerisinde MÖ 430-420 yıllarına tarihlenen karınlı bir krater üzerinde yine pulluk sürme sahnesi görülür. Bk. Immerwahr 1964, 24-25, no.7

9 Üvendire, çifte sürülen öküzleri yönlendirmek için kullanılan ve uç kısmına sivri demir/çivi takılmış uzun değnektir. Bu sivri demire "nodul" veya "modul" ismi verilir. Anadolu ağızlarında üvendire; "üğendire" veya "meses" olarak ta adlandırılmıştır. Eren 1999, 429; Üvendire, "öğendire" biçiminde de söylenmektedir. Tokat 2014, 163.

10 Saban/Pulluk, biri uzun diğeri kısa iki dayanıklı ağaç/ahşap parçanın eklenmesi ve kısa ahşap aksamın uç kısmına toprağı derinden yaran demir aksamın takılmasıyla kullanılmıştır. Sabanın hareketi bir tutma koluyla kontrol edilmiş olup tek öküzün çektiği sabanlarda tutma kolunun uç tarafındaki halkaya geçen kayış hayvana bağlanırken, iki öküzün çektiğinde ise çekme kolunun uç kısmına boyunduruk adı verilen bir parça eklenmiştir. Demirer 2013, 113.

11 Hörgüçlü öküz/boğanın ya da Hint öküzü/boğasının (Zebu/Zebus) anavatanı konusu tartışmalı olmakla beraber Afrika'dan öte Hindistan olduğu yönündedir. Hindistan'da Indus Vadisi yerleşimlerinde MÖ III. binyıl başlarından itibaren mühür ve figürinlerde görülür. Erken örneklerde erkeğin üremesiyle ilgili kültlerle ilintili olduğu düşünülmektedir. MÖ II. binyılın ikinci yarısında terrakota boğa figürinleri Susa ve Umm el Marra'dan ele geçmiştir. MÖ 950 civarında Filistin'de terrakota hörgüçlü boğa figürinleri bulunur. Hellenistik Dönem'de MÖ 281'den sonra basılan Seleukeia/Tralleis basımı sikkelerde, MÖ II. yüzyılda ise Antiocheia, Magnesia ve Smyrna sikkelerinde görülür. Yine MÖ 189-184 yılları arasındaki Kibyra bronz sikkelerinde yaygın tip hörgüçlü boğadır. Bu dönemde geniş bir ova ile ovaya hâkim kentte hörgüçlü boğanın yetiştirildiği ve ekonomide önemli olduğu söylenebilir. Roma İmparatorluk Dönemi'ne örnek olarak MS I. yüzyıla ait Tralleis'te bulunan boğa figürini gösterilebilir. Bk. Çağdaş 1955, 58; Özüdoğru 2014, 178; Çekilmez 2015, 53; Ayrıca bk. Akçay-Gürel 2018, 12, fig. 8. 
Üzerinde tunik bulunan çiftçi, ana uyar biçimde sol ayağı ile sabana basmaktadır ${ }^{12}$. Perspektifi verebilmek adına öndeki öküze göre arkadaki öküz daha büyük tutulmuştur ve olasılıkla saban sürmenin zorlayıcı olduğunu gösterebilmek için arkadaki öküzün sol ön bacağı dizden hafif bükülerek ileri atılmış ve sahneye hareket kazandırılmıştır. Öküzlerin özellikle gözleri ve boynuzları belirgin verilmiştir. Boyunduruk, öküzlerin hörgüçlerinin hemen önünde konumlandırılmıştır (Fig. 6-7).

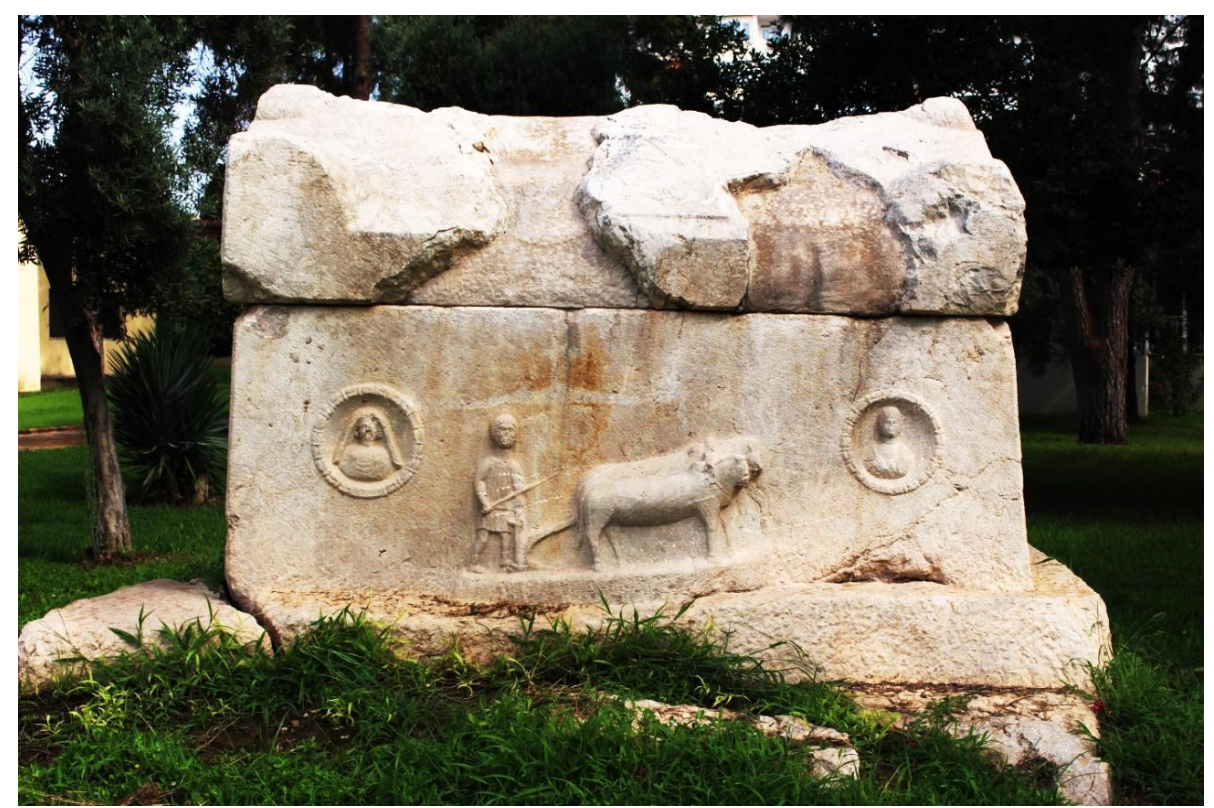

Fig. 5. Antalya Müzesi, Hurma Lahdi Ön Yüz

Hurma Lahdi üzerinde saban betimi bulunması nedeniyle antikçağ sabanlarını incelemek yararlı olacaktır. Antikçağda pulluklar; tamamen ağaç olup değişebilen veya değişemeyen kazıcı saban aksamı simetrik pulluklar, saban demirli simetrik pulluklar, tekerlekli pulluklar, arabalı/sepetli pulluklar ve genelde arabalı/sepetli saban demirli asimetrik pulluklar şeklinde sınıflandırılmışlardır. Ayrıca yaygın kullanılan basit pulluklar; taban ve saban demiri dikey olanlar, taban ve saban demiri yatay olanlar şeklinde iki tipe ayrılabilir ${ }^{13}$.

Roma Dönemi'nde saban, aratrum olarak isimlendirilir. Aratrum sözcüğünün pulluğun toprağı yarıp kenarlara yığmasından dolayı arruit fiilinden türediği önerilmiştir. Sabanın sivri uçlu demir kısmı vomer (vomis), tabanı dentale (dens), taban üzerinde duran düz ahşap bölüm stiva, tutamak kısmındaki sap manicula ve saban gövdesi ise buris (bura) olarak adlandırımışıı ${ }^{14}$.

Hurma Lahdi üzerindeki saban ise üç parçadan oluşmaktadır ve buris ile dentale birleşik işlenmiştir. Vomer ise dentale kısmına demir vb. bir bilezik ile sabitlenmiştir. Ayrıca stiva'nın, dental'eye ek bir aksam kullanılarak yerleştirildiği ve böylece dentale kirişinin gerisinde çiftçinin basabileceği boş bir zeminin oluştuğu anlaşılmaktadır (Fig. 6, 8).

12 Roma tarımında kölelerin kullanımına bağı olarak lahit üzerinde çift süren erkeğin köle olabileceği düşünülebilir. Ancak böyle bir lahdi yaptıran kişinin köle olmayacağı ve bu nedenle toprak veya çiftlik sahibi bir kişi olması gerektiğini belirtmek gerekir.

13 Joolen 2003, 105-107; Pulluk konusuna ilişkin ayrıca bk. White 1967, 123 vd.; White 1970, 174-178.

14 Varro, De Lingua Latina V. XXXI. 135; Ruperti 1841, 422; White 1967, 123 vd.; Neumann 1981, 223 vd. 


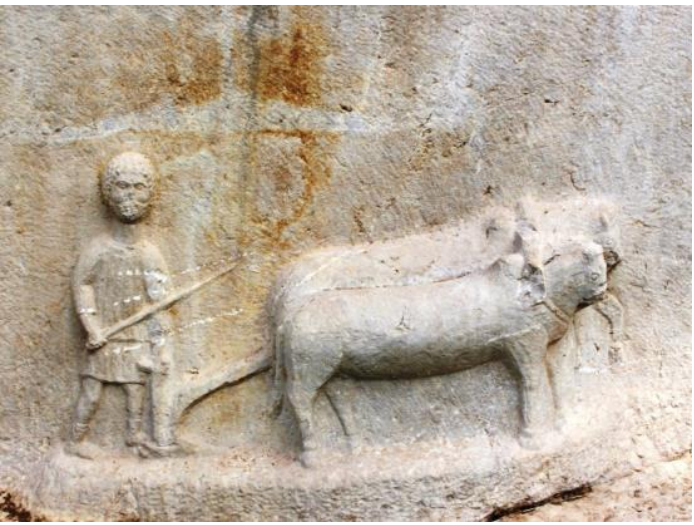

Fig. 6. Çift Sürme Sahnesi Cephe Görünümü

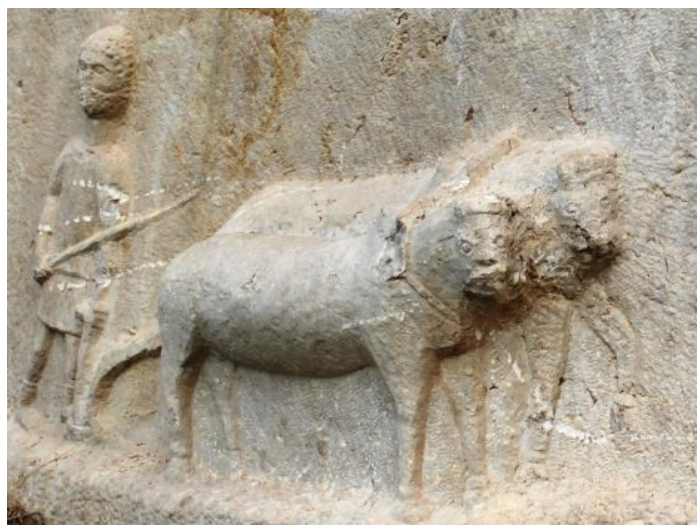

Fig. 7. Çift Sürme Sahnesi Yandan Görünüm

Hurma Lahdi'nde, karşıdan bakıldığında çift sürme sahnesinin önünde/sağında imago clipeata ya da clipeata imago ${ }^{15}$ veya çelenk $^{16}$ içerisinde cepheden verilmiş bir erkek büstü, arkasında/solunda ise yine çelenk içerisinde kadın başına şal ya da çarşafını geçirmiştir (Fig. 5, 9-10) ${ }^{17}$. Yerel üretim lahit üzerindeki figürleri portre bakımından karşılaştırmak çok sağlıklı olmasa da, ana sahnedeki kıvırcık saç ve sakallı yaşlı erkek ile büstteki kıvırcık saçlı erkek aynı kişi olabilir, dolayısıyla gençliğinden yaşlılığına uzanan süreçte adeta bir yaşam hikâyesi sergilenmiştir.

Lahitlerde büst kullanımı MÖ IV. veya III. yüzyıI ${ }^{18}$ gibi erken tarihlerde vardır; Roma İmparatorluk Dönemi Lahitleri üzerinde devam etmiştir ${ }^{19}$. Bu Dönem'de, kalkan veya tondo içerisinde portre büstler içeren lahitler, Erken Antoninler Dönemi'nden (150-160) itibaren görülür ve MS III. yüzyılda moda olur. Ayrıca Pamfilya Bölgesi osthoteklerinin ön yüzünde bulunan kavislerin içerisine çoğu zaman büstler yapılabilmektedir ve bunlar bir kadın ve/veya bir erkeği betimler ${ }^{20}$. Nitekim Hurma Lahdi büstlerindeki kişiler karı-koca olmalıdır ve lahit de belli ki ikisi tarafından ortak kullanılmıştır ${ }^{21}$.

Hurma Lahdi'nin her iki kısa yüzünde de, merkezinde rozet bulunan birer kalkan ve altında birer mızrak betimlenmiştir (Fig. 11-12, 23). Oldukça geniş kullanım alanı olan kalkan kabartmaları, tapınak ve konutların yanı sıra bir kült öğesi olarak kayalıklara da işlenmiştir ${ }^{22}$. Erken Hellenistik Dönem tarihli ${ }^{23}$ Termessos Alketas Mezarı, mezar geleneğiyle bağlantılı kalkan betimine iyi bir örnektir. Kalkan, burada diğer silah kabartmalarıla birlikte mezar sahibinin yüceltilerek heroize edildiğine, Anadolu'da tanrılaştı̆̆ına ve onun savaşçı kimliğine işaret eder ${ }^{24}$.

15 The J. Paul Getty Museum 1990, 80; Durugönül 2008, 195 vd.

16 Mezarlarda kullanılan çelenk hem zaferi hem de mezar sahibinin başarıları ile ödüle işaret etmektedir, bk. Öztürk 2003, 17.

17 Çelenk içerisinde büst örneği için bk. Koch - Sichterman 1982, 214, res. 283; Çelgin 1990, 260-268, res. 445-449.

18 Örneğin Hoyran'da MÖ IV. veya III. yüzyıla tarihlendirilen (tamamen Hellenistik Dönem olabileceği de belirtilmiştir) iki lahit üzerinde aslan ve boğa başlarının yanı sıra kadın büstü bulunur. Özer 2014, 81.

19 Örnekler için bk. Lanckoroński 1890, 6, res. 2; Kranz 1984, 191 vd.; 1999, 138 vd.; Özdilek - Çevik 2009, 285 vd.; Özer 2014, 80-86; Tüner Önen et al. 2017, 346 vd.; Çelik et. al. 2018, 182-184,

20 Koch 2001, 68 vd.; Üzerinde büst bulunan Roma (MS II-III. yüzyıl) lahit örnekleri için bk. Koch - Sichterman 1982, $117 \mathrm{vd}$.

21 Termessos’ta MS 150-200 arasına tarihlendirilen, Ailia Kapetoleina Kille adlı bir kadın ve kocası için yaptırılan lahde ilişkin bk. Çelgin 1990, 260-268.

22 Çevik 1996, 65.

23 Lanckoroński 1892, 68; Abbasoğlu 1987, 214; Çelgin 1994, 158-160.

24 Işık 2015, 204; Ayrıca kalkan kabartmalarının mezarlarda kullanımına örnek Antalya ili, Kemer İlçesi, Beycik Mahallesi sınılarında bulunan ve Hellenistik Dönem özellikleri gösteren Fırıncık Mevkii Antik Yerleşimi Nekropolü’ndeki mezar yapısı gösterilebilir. Bk. Çelik 2017, 96-97. 


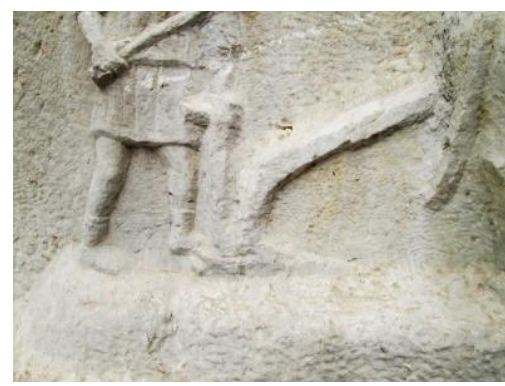

Fig. 8. Saban Detay

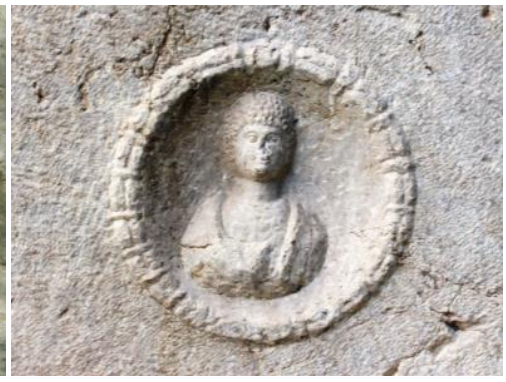

Fig. 9. Erkek Büstü

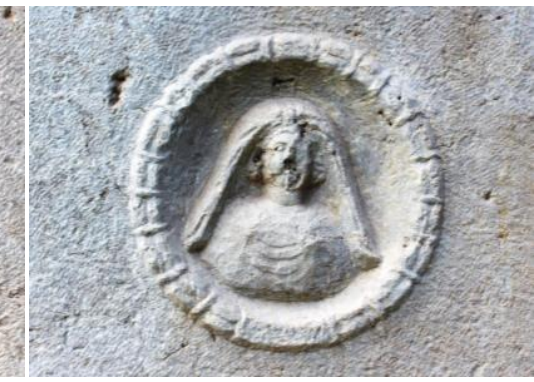

Fig. 10. Kadın Büstü

Trebenna Trokondas Mezarı Roma Dönemi'ne aittir ${ }^{25}$ ve özel konumu, kült amaçlı kaya döşemleriyle bir Ölü Tapınağı görünümü sergileyen bu mezarın kapısının üzerindeki kalkan ve mezar alanının dinsel içerikli düzenlemesi, Termessos Alketas Mezarı ile aynı düşüncenin bir başka yansımasıdır ${ }^{26}$.

Pisidia'da Hellenistik Dönem'den itibaren osthotekler üzerinde silah (kalkan ve kılıç) betimleri görülür. Bunun bir devamı olarak Roma İmparatorluk Dönemi Pisidia Lahitleri üzerinde de silah ile süsleme geleneği sürmüştür, bunlarla figüratif unsurlar belirli bir kalıba uyarlanmış ve lahdin uzun yüzlerindeki merkezi tabula ansatanın her iki yanına birer kalkan ve altında birer mızrak yerleştirilmiştir ${ }^{27}$.

Hurma Çiftçi Lahdi'nin üzerindeki kalkan betimlemeleriyle Pisidia geleneğini yansıttığı ve bulunduğu yerin Phaselis teritoryumu kuzeydoğu uç sınırları içerisinde bulunduğu söylenebilir ${ }^{28}$. Phaselis teritoryumu içerisinde bulunsun ya da bulunmasın hemen batıdaki dağlık bölge civarında, Hurma Çiftçi Lahdi'ne özellikle kalkan-mızrak ve büst betimlemeleriyle son derece benzer olan ve adeta kendine özgü bir sanatla yerel üretim başkaca lahit örnekleri tespit edilmiştir. Bu lahitlerdeki zenginliğin oluşmasındaki asıl etkenin Lykia, Pamphylia ve Pisidia kültür bölgelerinin geçiş sahasında bulunmaları olduğu söylenebilir. Ayrıca bu kadar birbirine benzer ikonografiye sahip lahitlerin durumu gözönüne alınırsa döneminin lahit geleneğine hâkim olup, siparişler üzerine lahitler yapan gezici yerel ustaların var olduğunu söylemek de mümkündür ${ }^{29}$.

Lahdin yaklaşık $10 \mathrm{~m}$ doğusunda dolgu toprak üzerine bırakılmış halde küçük parçaların dışında kapağa ait üç büyük parça bulunmuştur ve bunların eski kırık olmasına bakılarak lahdin günümüzden çok önce (belki de antik soygun!) soyulduğu anlaşımıştır. Söz konusu kapak parçaları, mümkün olduğunca birleştirilerek lahdin üzerine yerleştirilmiştir.

Hurma Lahdi kapağının her iki alınlığında Medusa ${ }^{30}$ başı bulunur (Fig. 11-12, 23). Medusa

25 Trokondas Mezarı (Kaya Mezarı 1), Trebenna'daki en nitelikli kaya mezarıdır. Mezar kapısının üstünde bir kalkan ve kapı üst yanlarında sarmaşıkla bezenmiştir. Kalkanın sol yanında 'Hermaios oğlu Trokondas'ın mezarı. Trebimes Herosları Diktirdi. Trokondas yaptı' yazmaktadır. Bu mezarın en geç MS I. yüzyıla tarihlenmesi gereken, kurucu ailenin bilinebilen tek kaya mezarı olması beklenir. Bk. Çevik et. al. 2005, 67-68.

26 Işık 2015, 204.

27 Üzerinde kalkan betimi bulunan Roma Dönemi lahit örnekleri için bk. Koch - Sichterman 1982, 544-550; Çelgin 1990, 88 vd.; Koch 2001, 259-261; 2010, 31-32; Pisidia lahitlerinde kullanılan kalkan, savaş̧̧ılığı göstermenin yanında, düşmana karşı hazırlık, güç, iktidar, hâkimiyet ve kötülüklerden koruyup caydırma gibi anlamlar içermektedir. Bk. Özdilek 2006, 34-36; Roma Dönemi Pisidia Lahitleri'nin genelinde tabula ansata ve iki kalkan bulunur. Yazıtları ve kabartma stilleriyle MS III. yüzyıla tarihlenebilirler. Özdilek - Çevik 2009, 284; Konuyla ilintili Phaselis teritoryumu ve yakın çevresinde Pisidia geleneğini yansıtan kalkan betimli lahit örnekleri bk. Tüner Önen et al. 2017, $346 \mathrm{vd}$.

28 Hurma-Liman bölgesi, haritalarda Phaselis teritoryumunun kuzeydoğu uç sınırları içerisinde gösterilmektedir. Bk. Tüner Önen 2008 33, lev. 2; Gürel 2016, 280, fig. 1.

29 Çelik et. al. 2018, 194.

30 Medusa Hellen Mitolojisi'nde, saçları yılanlarla örülü, tunç elli, altın kanatlı olan ve çevreye korku salan Gorgolar'dan ölümlü olanıdır. Bakışlarıyla insanı taşa çeviren Medusa'yı Kahraman Perseus başını keserek 
korkutucu ve koruyucu özelliğinden dolayı mezarlarda kullanılmış ${ }^{31}$, mezar ikonografisinde yerini Roma'dan çok önce almıştır ${ }^{32}$. Medusa başları Roma Dönemi'nde özellikle girlandlı lahitlerde çelenk boşluklarını doldurur ${ }^{33}$. Ayrıca Medusa başının ana/merkezi figüratif unsur olarak kullanıldığı lahit teknesi örnekleri ${ }^{34}$ bilinmekle birlikte, üçgen alınlıklı lahit kapakları üzerinde de yaygındır $r^{35}$.

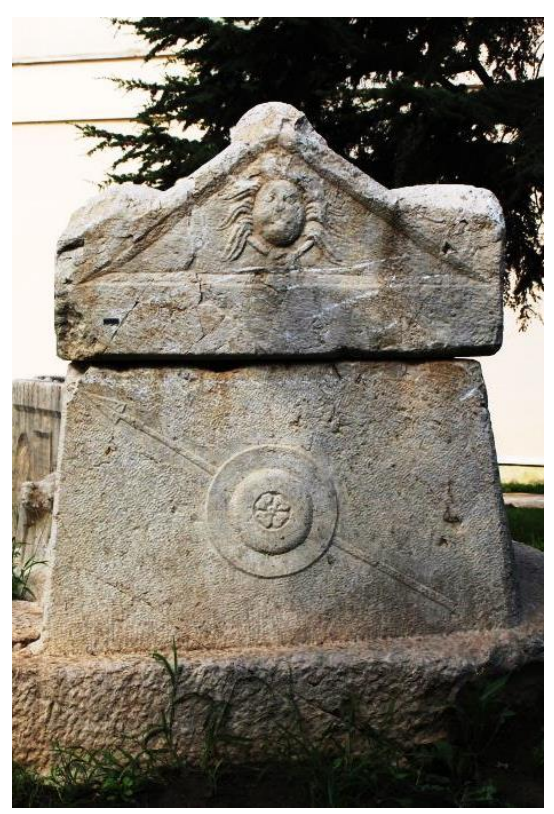

Fig. 11. Sağ Dar Yüz

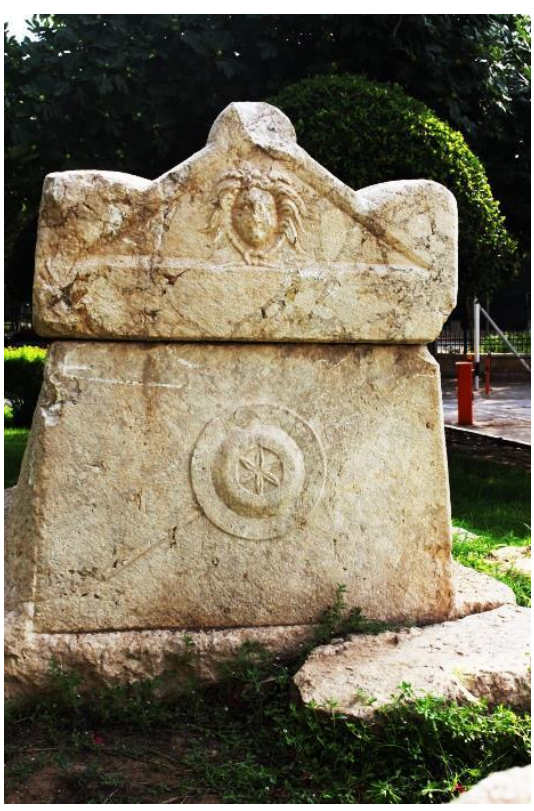

Fig. 12. Sol Dar Yüz

Lahit kapağının ele geçen parçalarından biri üzerinde bir bölümü tahrip olmuş tabula ansata bulunur (Fig. 14). Tabula ansata'lar, çoğu zaman üç köşeli veya sarkaç biçimli kulpludur, "kulplu anı tabelası" anlamına gelir ve bunlar genelde yazıt amaçıdır. Lahit teknesi dışında bazı lahit kapaklarında da bulunabilirler ${ }^{36}$. Hurma Lahdi kapağı üzerindeki tabula yazısızdır; boş bırakılmıştır. Kapağın tepe ve köşe akroterlerinin sadece genel hatları oluşturulmuş ve başkaca herhangi bir bezeme veya figür işlenmemiştir ${ }^{37}$.

Konunun daha iyi anlaşılabilmesi bağlamında üzerinde saban betimi bulunan sikkeleri incelemek yerinde olacaktır. Bu tip sikkelerin en erken örneği olarak Makedonyalı Büyük İskender Dönemi'ne ait Tarsus sikkeleri gösterilebilir ve bunların arka yüzünde tahta oturan Zeus'un

öldürmüştür. Erhat 1972, 149; Fuchs 1979, 397-398, 407; Grimal 1997, 217-219; Carpenter 2002, 106 vd.

31 Lahitlerde Medusa başları, mezarın korunması ve bekçilik yapmaları amacıyla kullanılmıştır. Şimşek 1998, 4.

32 Örneğin Limyra'dan Antalya Müzesi'ne getirilen ve MÖ 380-360 yılına tarihlendirilen semerdam biçimli lahit kapağının dar yüzünün üst kirişi üzerinde bir Medusa başı bulunur. İdil 1981, 86-87, lev. 31.1-2.; Yine MÖ 370-360 yıllarına tarihlenen Perikle Heroonu üzerinde Perseus'un Medusa ile hikayesi konu edilmiştir. Bk. Borchhardt 1976, 83 vd.; Şahan 2009, 47-48.

33 Girland üstü boşluklarda Medusa başı kabartması kullanılan Roma Dönemi Girlandlı Lahit örnekleri için bk. McCann 1978, 31-33; Işık 1982, 35 vd.; Waelkens 1982, 20 vd.; Herdejürgen 1996, 83 vd.; Elsner 2018, 358, fig. 13.1

34 Koch - Sichterman 1982, 352, 500, res. 388, 483.; Waelkens 1982, 57, lev. 18,1; Huskinson 2015, 167.

35 İdil 1981, 54 vd., lev. 7.1, 36.1-2, 79.2; Waelkens 1982, 17, lev. 1,1; Cambi 2010, 63 vd; Çelik et. al. 2018, 182, 188-189.

36 Koch 2001, 28 vd.; Roma Imparatorluk Dönemi (MS II-III. yüzyıl) içerisinde kapağında tabula/tabula ansata bulunan lahit örnekleri için bk. Koch - Sichterman 1982, 67 vd.; Ayrıca Prokonnesos'ta üzerinde tabula ansata taşıyan çatı formlu lahit kapağı örneği için bk. Koch 2010, 15, 111, res. 20.3.

37 Bundan farklı olarak özellikle Anadolu lahitlerinin kapaklarının köşe akroterlerinde palmet ve/veya yapraklı düzenlemeler olabilir. Ayrıca bazen figürler de bulunabilmektedir. Bkz. Koch 2001, 205-212. 
önünde bazen saban gösterilmiştir ${ }^{38}$ (Fig 16). Fakat bu sikkelerden biraz daha erken olan yani Pers Dönemi'ne ait bazı Tarsus sikkelerinde taht üzerinde oturan Ba'al Tars bazen elinde üzüm salkımı ve/veya buğday başağı tutmaktadır ${ }^{39}$ (Fig 17).

Üzüm salkımı ve buğday başağı kompozisyonu Anadolu sanatında çok tanıdık bir unsurdur ve en azından MÖ X. yüzyıldan itibaren işlenmiştir ${ }^{40}$. Örneğin Yeni/Geç Hitit Dönemi (MÖ 730-720) İvriz Kaya Anıtı üzerinde Tanrı Tarhunzas ile Tabal Ülkesi Tuvana Beyi Varpalavas karşılıklı bir şekilde durmaktadırlar (Fig 18). Varpalavas daha küçük gösterilmişken, Tanrı Tarhunzas'ın sağ ayağından asma çıkmakta ve bu tanrı sağ eliyle üzüm salkımlarını sol eli ise buğday başaklarını tutmaktadır" ${ }^{41}$. Tarhunsaz, Hattilerin Taru, Hititlerin Teşup olarak adlandırdıkları "Göğün Baş Tanrısı" ile özdeştir ve İvriz Kaya Anıtı üzerinde "Fırtına Tanrısı Tarhunzas", "Üzümbağının Tarhunzası"na evrilmiştir". Bunun yanında Lidçe "Baki" sözcüğü Tanrı Dionysos'un "Bakkhos" isminin kökeni olabilir ve ayrıca Dionysos isminin türevi olan "Dionisikles" sözcüğünün Lidçe karşıllğı "Bakiva" olarak geçmektedir" ${ }^{43}$. Bu bağlamda MÖ VI. yüzyıl Hellen vazo resminde ayağından-vücudundan asma filizlenen Dionysos’un öncüsü ve de kökeni İvriz Kaya Anıtı üzerindeki Tarhunzas ve onu besleyen düşünceyi yaratan topraklar olmalıdır ${ }^{44}$.

İvriz Kaya Anıtı üzerinde Tarhunzas'ın sağ ayağından asma köklenip göğermişken sol ayağından ise bir demet buğday filizlenmektedir. Yani tanrısal gösterimde asma ile buğday arasında bir eşitlik söz konusudur. Kökeni Fırtına Tanrısı Taru/Teşup olan Tarhunzas'ın fırtına-şimşek-yağmur ile ilişkisi düşünüldüğünde suyla toprağı bereketlendiren bu tanrının ayaklarının toprağa değdiği yerden asma ve buğdayın fışkırması gayet makuldür ve bu gösterim Tarhunzas'ın ürünler üzerindeki yaratıı//hayat verici gücünü yansıtıyor olmalıdır ${ }^{45}$. Dağlık-ovalık Anadolu coğrafyası ve ikliminin hem üzüm hem de buğday tarımı için oldukça elverişli yapısı düşünüldüğünde Tarhunzas üzerinde özellikle bu iki ürünün eşit bir şekilde sembolize edilmesi son derece doğaldır ${ }^{46}$.

38 CNG Auction 85-2010, 61, nr. 282; CNG Auction 88-2011, 25, nr.111; Triton XVII-2014, 59, nr. 147; Triton XXI2018, 41, nr. 397.

39 CNG Auction 49-1999, 73, nr. 655; Triton XIII-2010, 70, nr. 1329-1330; Triton XVII-2014, 120, nr. 352-353; Triton XVIII-2015,31-35, nr. 71-73, nr. 75-81, 245, nr. 645-646; Triton XIX-2016,100, nr. 274; Triton XX-2017,110-111, nr. 329-331.

40 Yeni/Geç Hitit Dönemi kabartmaları üzerindeki üzüm ve/veya başak tasvirleri geç X - erken IX. yüzyıldan itibaren gösterilmiştir. Tiryaki 2013, 35 vd.; Ayrıca MÖ VIII. yüzyıla tarihlendirilen İvriz Kabartması ve Niğde Steli ile MÖ VIII-VII. yüzyıla? tarihlendirilen Gökbez Kaya Anıtı buna örnek gösterilebilir. Bk. Tiryaki 2001-2002, 68, res. 1a-3b.

41 Akurgal 1955, 85 vd.; Akurgal 1968, 135, 214; Akurgal 1998, 200; Tiryaki 2001-2002, 68, res. 1a-1b Muscarella 2013, 770; Turgut 2017, 7-12; İvriz Kaya Anıtı'nda ayrıca Luwi hiyeroglifli yazıt bulunur ve “...Tarhunzas bu bağı yetiştirsin, üzüm büyüsün, o yaprak versin ve o 1000 ölçü şarap olsun...” yazar. Bk. Hawkins 2000, 516 vd.; Tiryaki 2001-2002, 68; Bu yazıta ilişkin ayrıca bk. Hrozný 1937, 459 vd.

42 Tiryaki 2001-2002, 59; Tiryaki 2013, 43.

43 Gusmani 1995, 13; Tiryaki 2001-2002, 64; Işık 2012, 189; Özdemir 2016, 39.

44 Işık 1999, 66; Tiryaki 2001-2002, 64; Işık 2012, 189.

45 İvriz Kaya Anıtı́nda tanrı ile bey aynı düzlemde olmayıp Tarhunzas'ın ayaklarının bastığı zemin Varpalavas'ın durduğu zeminden daha aşağı seviyede gösterilmiştir. Tanrısallığına binaen Varpalavas'a göre oldukça büyük gösterilen Tarhunzas'ın başı kabartma çerçevesi sınırına kadar değdirilerek sanki "Göğün Baş Tanrısı" vasfına, bulut-şimşekfırtına-yağmur üzerindeki hâkimiyetine işaret edilmek istenmiştir. Bununla birlikte Tarhunzas'ın bereket, ürünler üzerindeki yaratıcı gücüne işaret etmek istercesine bu kez özellikle ayakları toprağın içine sokulmuş gibi Varpalavas'ın durduğu zeminden daha aşağı konumlandırılmış olmalıdır. Yani Tarhunzas, başı göklerde ve toprak içine nüfuz eder derecesinde ayakları yerlerde bir tanrı olarak bilhassa bu pozda gösterilmiş gibidir. İvriz Kaya Anıtı Sanatkârı, Tanrı Tarhunzas'ın toprak içine nüfuz ederek bereket vasfını iyice vurgulayabilmek adına mecburen tanrının ayaklarını Varpalavas'ın bulunduğu zeminden daha aşağıda konumlandırmış olmalıdır.

46 Ayrıca Hellas ana karasının genel olarak dağlık coğrafyasının üzüm tarımına daha uygun olması, en azından Anadolu gibi geniş ovalarının bulunmaması nedeniyle buğday tarımına daha az elverişli yapısı göz önüne alınırsa 


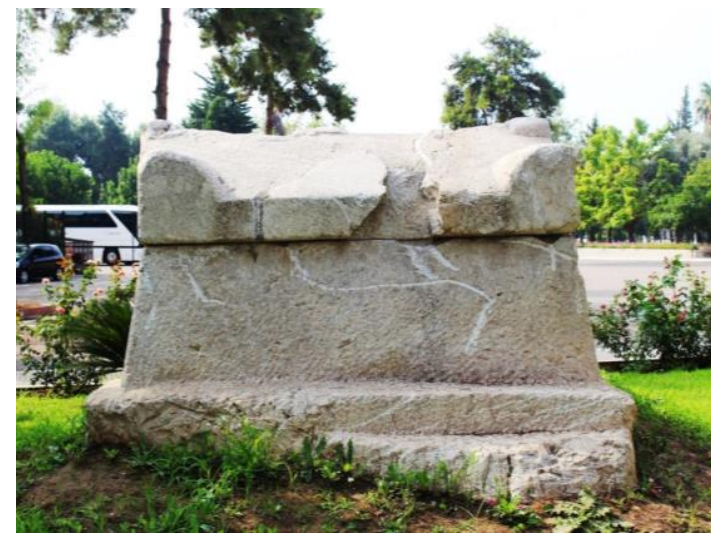

Fig. 13. Arka Yüz

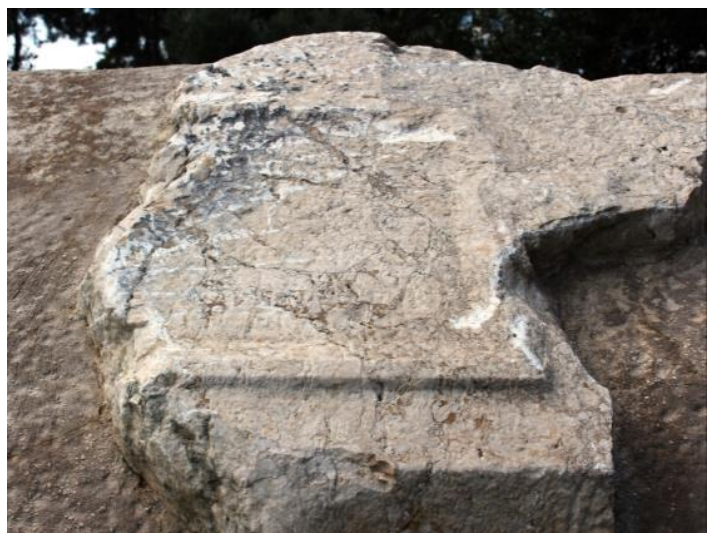

Fig. 14. Kapak Üzerindeki Tabula Ansata

Pers Dönemi Tarsus sikkeleri üzerinde Ba'al Tars'ın elinde görülen üzüm salkımı-başak demeti Yeni/Geç Hitit üzerinden gelen inanç siteminin bir çeşit yansımasıdır. Ayrıca asma-başak ikilisi bolluk, refah ve sonsuz yaşam isteminin göstergesidir ${ }^{47}$. Nitekim özellikle lahitler üzerinde görülmesiyle asma-üzüm, mezar ikonografisinde bir nevi hayat ağacı özelliğindedir ve öldükten sonra yaşam inancının bir belirtecidir ${ }^{48}$. Öyleyse asmanın dengi olan başak da aynı anlamı paylaşıyor olmalıdır. Bunun yanı sıra Makedonyalı Büyük İskender Dönemi Tarsus sikkeleri üzerinde tıpkı Ba'al Tars gibi betimlenen Zeus'un önünde görülen saban da yine asma-başak ile aynı anlamı taşımalıdır ve bu bağlamda bolluk ve refahı temsil etmesinin yanında mezar ikonografisinde ise hem adandığı şahsın çiftçilikle uğraştığını göstermeli ve hem de sonsuz yaşam veya öldükten sonra yaşam inancını sembolize etmelidir.

Üzerinde saban sürme betimi bulunan bir başka sikke grubunu, Roma Dönemi koloni sikkeleri oluşturur. Bu sikkelerdeki saban sürme betimi ise Romulus ve Remus efsanesine dayanıyor olmalıdır ${ }^{49}$. Nitekim Roma Imparatorluğu tarafından yeni kurulan koloni bir kentin sınırları saban/pulluk yoluyla belirlenmiştir. Bu nedenle koloni kent sikkelerinde saban/pulluk dışında, çift süren Augustus, çift süren rahip veya çift süren kolonistler şeklinde tasvirler de görülür ${ }^{50}$. Dolayısıyla koloni

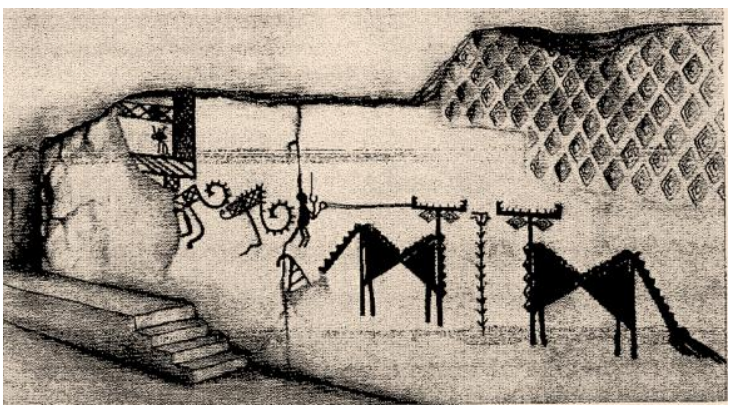

Fig. 15. Aslantepe. Çift Sürme Sahnesi (Işık 2015, 50, Fig. 18) sikkeleri üzerinde görülen çift sürme sahnesi, özellikle o kentin sınırlarının belirlenmesine ilişkin

eğer, üzümün önemi doğrultusunda Hellen ana karasında Dionysos inancının özellikle şarap etrafında yoğunlaşması tabii karşılanmalıdır. Anlatılmak istenen Hellas coğrafyası, Anadolu gibi hem üzüm hem de buğday üretimine eşit derecede bu denli müsait olsaydı, beslendiği öz Tarhunzas gibi Dionysos da Hellas'ta sadece şarap değil, belki özellikle eşit oranda şarap-başak tanrısı olarak tapınım görecekti?

47 Tiryaki 2013, 45-46.

48 Çelik et. al. 2018, 187

49 Mitolojiye göre Rhea Silvia, Savaş Tanrısı Mars'tan hamile kalmış, Romulus ve Remus adında ikiz oğlan çocuğu doğurmuştur. Amulius tarafından Tiber Nehri sularına bırakılan, bir kurt tarafından emzirilen, bir çoban tarafından büyütülen bu iki kardeş delikanlı olunca Alba Şehri'ne gidip Amulius'u öldürürler, Numitor'u tahta çıkarırlar ve Tiber Nehri'nden sahile sürüklendikleri yerde bir şehir kurma hakkı kazanırlar. Fakat bu işe başladıklarında aralarında anlaşmazlık çıkınca Romulus kardeşi Remus'u öldürmüştür. Demircioğlu 1953, 36-37; Romulus kutsal bir hendek kazarak Roma Kenti'nin sınırlarını belirlemiştir. Colledge 1982, 3.

50 Sancaktar 2009, 103 vd. 
olup, doğrudan kırsal yaşam ve/veya çiftçilikle bağlantılı değildir. Bununla beraber Roma sikkelerinde görülen saban gösteriminin sınırları belirlendikten sonra bir düzen içinde kurulan şehirlerdeki bolluk, bereket ve refahı dolaylı yoldan da olsa işaret ettiği düşünülebilir.

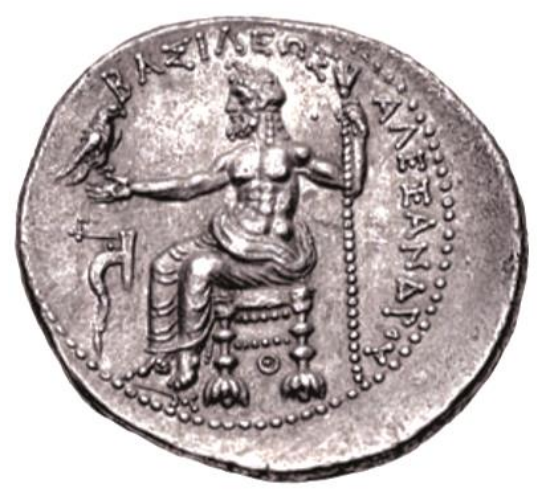

Fig. 16. İskender Dönemi Tarsus Sikkesi (CNG Auction 84-2010, 49, nr. 262)

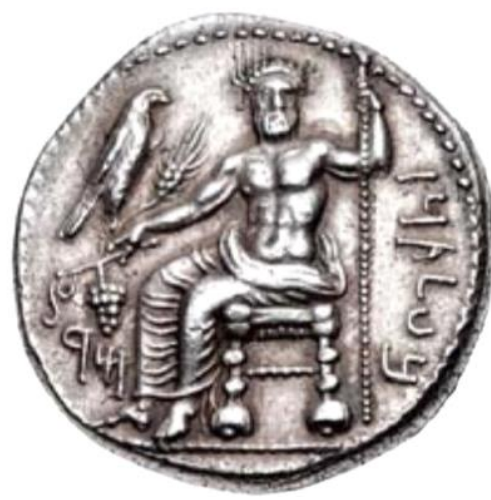

Fig. 17. Pers Dönemi Tarsus Sikkesi (Triton XVI-2013, 148, nr. 532)

Roma'nın ilk kurulduğu zamanlarda eşit toprak dağııımı düşüncesi geçerliyken zamanla özellikle patrici adı verilen büyük toprak sahiplerinin pleb’lerin yani küçük toprak sahiplerinin mülküne el koyduğu bir tür feodal sistem ortaya çıkmıştır. Bununla beraber Roma'da araziler, ager publicus (kamu arazisi) ve ager privatus (özel arazi) biçiminde ikiye ayrılmaktadır, fakat tarım daha çok kamu arazisi üzerinde yapılmaktadır. Patrici-pleb huzursuzluğunun son derece artığı MÖ 133 yılında toprak reformu süreci başlatılmış, bunun sonucunda yaklaşık yüzyıl sürecek bir iç savaş vuku bulmuş, daha sonraki süreçte ise Roma toprak sistemi ve hukuku bu temel üzerine gelişip devam etmiştir ${ }^{51}$. Roma Dönemi'nde büyük mülk sahipleri, topraklarının işletilmesi için köleleri kullanarak büyük gelirler elde etmişlerdir. Roma'da tarım için kullanılan köleler iki grup altında toplanabilir. Bunlardan ilk grup en ağır işleri yapan kölelerden oluşur. ikinci grubu ise bu kölelerin çalışma ve denetlenmesinden sorumlu olan ve çiftlik sahibinin sağ kolu durumundaki vilcius adı verilen bir tür kâhya pozisyonundaki köleler oluşturur ${ }^{52}$. Ayrıca Roma tarımında saban ile toprağın sürülmesi sonucu buğday, arpa, darı gibi tahılların yanı sıra mercimek ve fasulye gibi bakliyat yetiştirildiği bilinmektedir ${ }^{53}$.

51 Roma'nın ilk kurulduğu MÖ VIII. yüzyıl ortalarından itibaren ailelere eşit toprak dağıtımı esası geçerliyken zamanla toprakların genişlemesi sonucu özellikle verimli topraklar ager publicus yani kamu toprağı sayılmış, latifundium adı verilen büyük çiftliklerin sayısı artmış, patrici ve aristokrat toprak sahipleri küçük toprak sahipleri yani pleb’lerin topraklarına el koymaya başlamış ve bir tür feodal sistem ortaya çıkmıştır. Bunun yanında Roma'da araziler, kamu arazisi (ager publicus) ve özel arazi (ager privatus) biçiminde ikiye ayrılmıştır, ancak özel arazilerin kapsamı sınırlı olduğundan tarım genel olarak kamu arazileri üzerinde yapılmıştır. Ayrıca kamu arazisinin mülkü devlete ait iken intifa hakkı toprağı işletene/işgal edene tanınmaktadır. Patrici ile pleb’lerin arasındaki huzursuzluğun arttığı bir dönemde MÖ 133 yılında Tiberius Gracchus Roma Senatus'una halk temsilcisi yani tribunus olarak seçilmiş, Romalı zenginlerin topraklarının bir kısmının alınıp toprağı olmayan insanlara dağııılmasını önermiş ve toprak reformu sürecini başlatmış, ancak bu önerisinin bedelini MÖ 132 yılında senatoda dövülüp canıyla ödemiştir. Tiberius Gracchus'un ölümünden sonra MÖ 123 yılında bu kez kardeşi Gaius Gracchus, tribunus olarak seçilmiş, ağabeyinin gittiği yolu takip ederek tahıl yasası (lex frumentia) ile vergi ve adalet sistemini düzenleyen yasalar çıkartmış, bu yasa ile halk pazardan artık daha ucuza buğday alma imkânına kavuşmuştur. Fakat MÖ 121 yılında yine senatoda tıpkı ağabeyi gibi o da katledilmiştir. Roma Devleti'nde Tiberius Gracchus'un başlattığı reform hareketleri yaklaşık yüzyıl sürecek bir iç savaşa sebep olmuştur. Bk. Aydoğdu 2016, 375- 381

52 Saydam 2018, 82; Ayrıca Roma'da tarımın ekonomideki büyük yeri nedeniyle doğal olarak saban ve kullanımı çok önemlidir. Roma'nın Avrupa topraklarını ele geçirmesiyle beraber bu bölgeler sabanla tanışmış, kölecilik artmış ve tarımsal faaliyetler hızlanmıştır. Bk. Şanlıbayrak 2013, 59-61.

53 Aldrete 2004, 188; Erdkamp 2005, 47-49; Morley 2010, 50. 
Batı Anadolu'da kırsal yaşam konusuyla bağlantılı olarak, aralarında MS I. yüzyıl örneği olmakla beraber, genelde Roma Geç İmparatorluk Dönemi içinde üzerinde çift sürme sahneleri bulunan bazı mezar stelleri görülür. Bu stellerde tek kişi ile çift sürme dışında başkaca sahneler de bulunur ${ }^{54}$. Ayrıca Roma Dönemi'nde mozaik sanatında da çift sürme sahnesi gösterilmiştir ${ }^{55}$.

Roma İmparatorluk Dönemi'nde kırsal yaşam konusu, lahitler üzerinde sevilerek işlenmiştir. Özellikle çoban betimleri bulunan çok sayıda lahit ve kapağı, kır yaşamı veya 'bukolik' başlığı altında toplanır. Çobanlar, lahitlerde mitolojik konularla birlikte kapakta ve yan yüzlerin fazlaca görünmeyen kısımlarında betimlenmişlerdir. Bu tip lahitler Antoninler Dönemi'nden itibaren görülür ve MS IV. yüzyılda da devam eder ${ }^{56}$. Bununla beraber, Roma lahitleri içerisinde bir çift öküzle saban sürme sahnesi nadiren de olsa vardır. Ancak bu örneklerde saban sürme ana sahne olmayıp yan bir sahne veya genel sahnenin bir parçası olarak değerlendirilmiştir ${ }^{57}$.

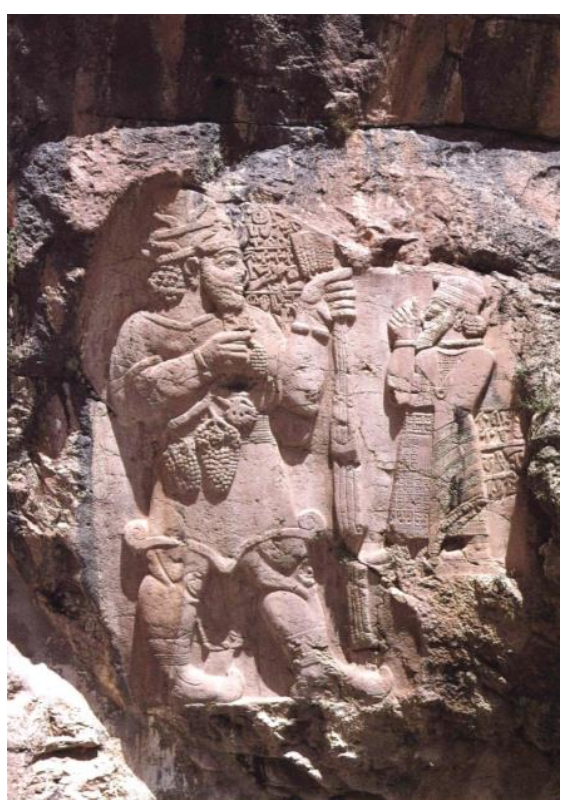

Fig. 18. İvriz Kaya Kabartması

(Akurgal 1995, Levha 133)

Beydağları civarında ise Roma İmparatorluk Dönemi'nin MS III. ve IV. yüzyılları içinde kırsal yaşam konulu yerel üretim lahitler tespit edilmiştir. Bunlar dönemin bölgedeki çiftlik ve tarım alanlarındaki tarımsal faaliyetlerine tanıklık etmesi, o günkü bitki ve hayvan çeşitliliğini yansıtması ve kırsal yerleşmelere ilişkin kayıtları göstermesi bağlamında önemlidir. Bunlar arasında çoban konulu örneklerin dışında, saban görülmese de, çift sürme sahnesi olduğu anlaşılan lahit örneği de bulunur ${ }^{58}$. Bu tip sahneler mezar sahibinin yaşadığı kırsalı çoban veya çiftçi kimliğiyle birarada gösteriyor olmalıdır.

54 Kyzikos, Bursa, Zemme, Altıntaş, Kotiaeion ve Bithynia örnekleri üzerinde saban sürmenin dışında büstler, kline sahnesi, stel sahibinin annesi, tanrı ve yazıta ek olarak sopa, çekiç, keski, iğ gibi objeler de bulunabilmektedir. Bk. Pfhul - Möbius 1979, 283-285, res.1143-1158; Ayrıca üzerinde çift sürme sahnesi olan ve MS IV. yüzyıla tarihlenen İznik Müzesi'nden bir mezar steli örneği için bk. Şahin 1981, lev. 5, nr. 767; Bunun dışında Bursa Arkeoloji Müzesi'nde 2604 Envanter Numaralı olan ve üzerindeki çift sürme sahnesiyle Hurma Çiftçi Lahdi'ne benzeyen mezar steli, Çanakkale Onsekiz Mart Üniversitesi, Sosyal Bilimler Enstitüsü’nde "Batı Anadolu'da Roma İmparatorluk Dönemi'nde Tarım” başıkı doktora tez çalışmalarını sürdüren Ömer Can Yıldırım tarafından MS. IIIII. yüzyıla tarihlenmektedir. Buna ek olarak Kütahya Müzesi 406 Envanter Numarasına kayıtlı olup, MS 304-305'e tarihlenen ve ebeveynleri tarafından 19 yaşında ölen oğulları Leon için yaptırılan mezar stelinde alt bölümde saban-bir çift öküz betimi bulunurken Leon elinde ucu sivri bir üvendire tutmaktadır. Bu bilgileri bizimle paylaşması ve değerli önerileri nedeniyle Ömer Can Yıldırım’a teşekkür ederiz.

55 Roma Dönemi içerisinde MS III. yüzyıla ait çift sürme sahneli mozaik örneği için bk. Morley 2010, 51.

56 Koch 2001, 100-101.

57 Kısa yüzünde çift sürme sahnesi bulunan Louvre Müzesi'ndeki Triptolemos Lahdi, MS 150-170 yıllarına tarihlenmektedir. Koch - Sichterman 1982, 187-188; Louvre Triptolemos Lahdi kısa yüz detayı için bk. Musée du Louvre 1985, 120; MS 270-290 yıllarına tarihlendirilen bir sahnede, sepet taşıyan, uzun saplı buğday başakları istifleyen ve taşıyan figürlerin yanında kıvırcık saç ve sakallı bir çiftçinin öküzleri sabana koştuğu görülür. Bielefeld 1997, 100, res. 69.3.

58 Beydağları Yüzey Araştırmaları ekibince 1997-2006 yılları arasında Likya, Pamfilya ve Pisidia sınır bölgelerinde kalan Trebenna, Kelbessos, Typalia, Hurma, Kartınpınar ve Gedeller gibi yerlerde kırsal yaşam konulu çok sayıda lahit tespit edilmiştir. Bu lahitlerin çoğu Pisidia motifleri taşımakla beraber bunların bir bölümü Tabula AnsatalıKalkanlı ve Tabula Ansatalı-Figürlü olarak iki başık altında değerlendirilmiştir. Bu lahitler yazıt ve genel stilistik özellikleri ile Roma Dönemi içerisinde MS III-IV. yüzyıla tarihlendirilmişlerdir. Kartınpınarı'nda tespit edilen bir örnekte ise saban gösterilmeksizin bir çift öküz sahnesi görülür. Özdilek - Çevik 2009, 284-287, fig. 9. 


\section{Tarihlendirme}

Roma İmparatorluk Dönemi içerisinde özellikle Antoninler Dönemi (138-193) portreleri oldukça perdahlıdır ve yüzler parlaktır. Saç ve sakal havalıdır, perçem ve/veya buklelerin hatları derin matkap izleriyle belirginleştirilmiştir. Gözler büyüktür, göz kapakları ağırdır. Göz bebekleri matkabın hafif nokta darbesi ile betimlenmiştir. Portrelerde genel olarak dalgın ifade ile huzurlu bir hava hâkimdir ${ }^{59}$. Severuslar Dönemi (193-235) genel görünümü itibariyle Antoninler Dönemi'nin devamcısıdır ve yine saç ve sakal genelde kıvırcıktır ve hatları belirgindir ${ }^{60}$. Yerel üretim bu lahit üzerinde yer alan erkeklerde portre özelliklerini tespit etmek mümkün görünmemekle birlikte kıvırcıklı saç ve sakal yapısı önemli ipucu vererek Antoninler-Severuslar Dönemi'ne işaret ediyor olmalıdır. Ayrıca Beydağları civarında kırsal yaşam konulu yerel üretim lahitlerin Roma Imparatorluk Dönemi içerisinde MS III. ve IV. yüzyıllara tarihlendiği, ancak kıvırcıklı saç gösterimi ile lahdin Antoninler-Severuslar Dönemi'nden çok uzaklaşmaması gerektiği, bunun yanı sıra hızla yayılan Hristiyanlığa ilişkin üzerinde herhangi bir göstergenin bulunmadığı düşünülürse Hurma Çiftçi Lahdi Roma Imparatorluk Dönemi içerisinde MS III. yüzyıla tarihlenebilir.

\section{Lahdin Konumlandığı Arazi}

Hurma Mahallesi'nde bulunan lahdin podyumunda işlenmiş en alt sınır çizgisi, lahdin tarihlemesine paralel olarak Roma Dönemi zeminini göstermelidir ve lahdin kapağı da örtülü olduğuna göre, o dönemden günümüze yaklaşık 1.5 m toprağın yükseldiği söylenebilir (Fig. 19). Alanda açılan tüm sondaj çukurlarının kesitleri incelendiğinde, alanda killi veya killi-çakıllı bir dolgunun bulunduğu ve lahdin işlenmiş en alt sınırından itibaren yaklaşık 1-1,5 m derinlikte su çıktığı gözlemlenmiştir (Fig. 20). Bununla, Roma Dönemi'nde Hurma Mahallesi civarında genel olarak sulak bir arazi olasılığı bulunsa bile, en azından sırtı kayalık tepeye dayalı lahdin bulunduğu alanın yakın çevresinde, o dönem için de, daha kuru bir toprak zeminin olduğu ve buna bağlı tarım yapıldığı söylenebilir.

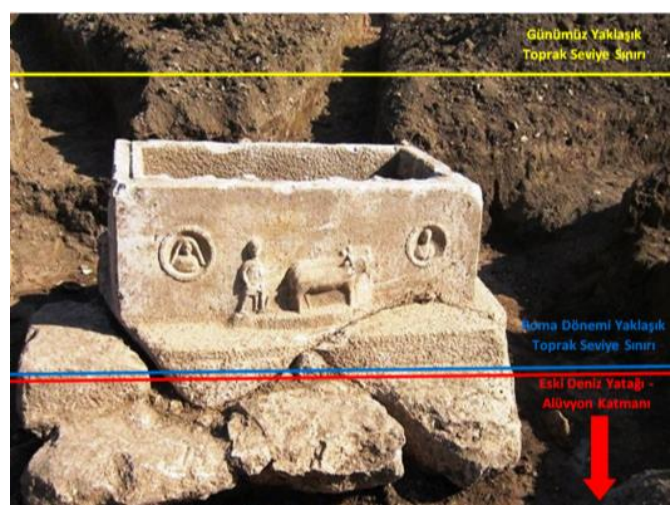

Fig. 19. Olası Toprak Seviye veya Katman Sınırları

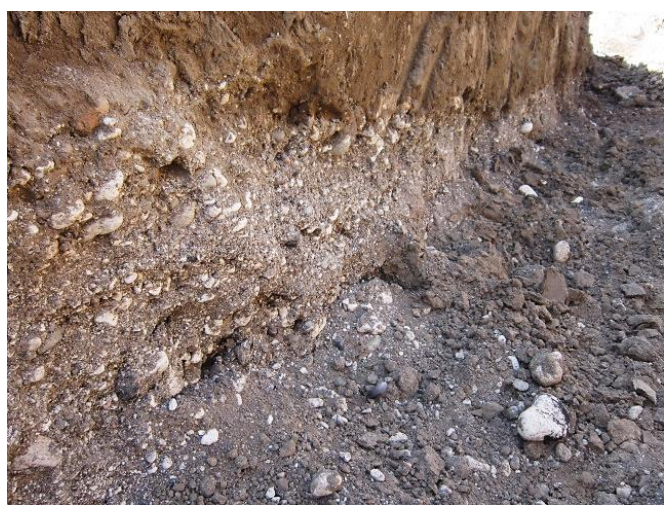

Fig. 20. Fig. 20- Killi-Çakıllı Sondaj Kesiti

Lahdin podyumunun doğal haliyle toprak altında kaldığı seviyede toprağın killi-çakıllı dokusundan; alanın Roma'dan çok önceki zamanlarda eski bir deniz tabanını oluşturduğu ve dolayısıyla tüm Hurma-Liman civarındaki düzlük arazinin binlerce yıllık bir zaman diliminde dolarak bir ova görünümüne kavuştuğu sonucu çıkarılabilir ${ }^{61}$ (Fig. 19-21).

59 Özgan 2013, 117-283; Ayrıca Antoninler Dönemi portre özelliklerini yansıtan örnekler için bk. Hekler 1912, 37, 262-270; Poulsen 1974, 113-126; Vermeule 1981, 320-339, res. 274-291; Karamut 1991, 607-610, res. 1-16; Delemen 2011, 104-117.

60 Severuslar Dönemi portre özelliklerini yansıtan örnekler için bk. Frel - Morgan 1987, 90-101; Long 2014, 223-224; O'Grady 2015, 97-101.

61 Son 15.000 yılda deniz seviyesinin 100 m kadar yükselmesi ve tektonik batma sonucu günümüzden yaklaşık 6.000 


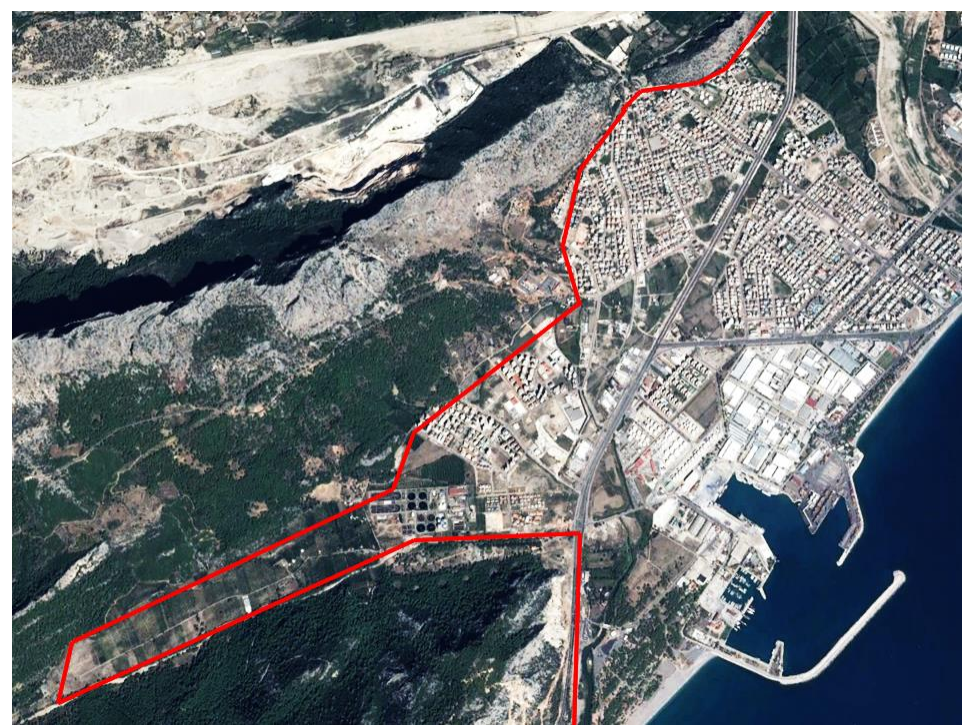

Fig. 21. Hurma-Liman Mahallesi Civarında Eski Deniz Tabanı Olduğu Düşünülen Yaklaşık Alan (Google Earth-09.08.2017)

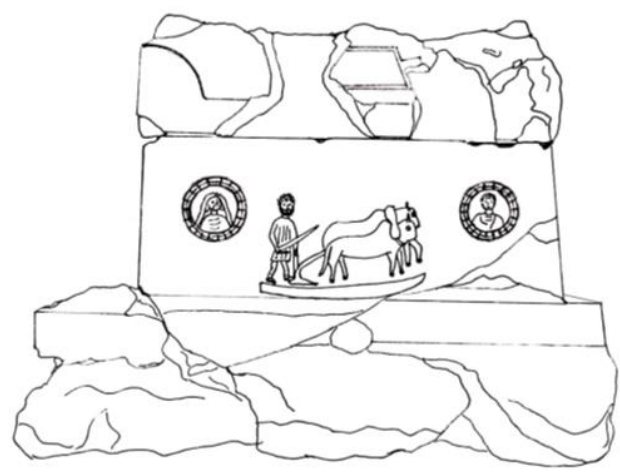

Fig. 22. Ön Yüz (Ölçek 1:60)

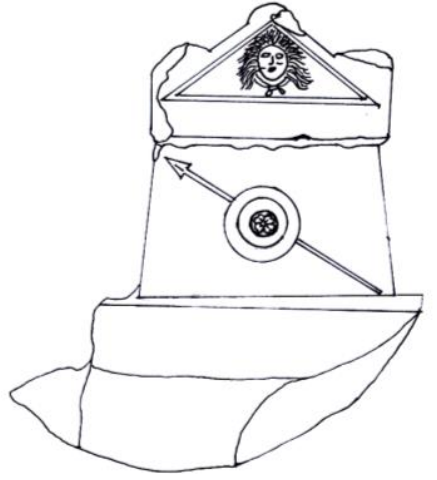

Fig. 23. Sağ Yüz (Ölçek 1:60)

\section{Sonuç}

Yerel kireçtaşı üzerine oyulmuş, yerel iş̧̧ilikli kırsal yaşam konulu Hurma Lahdi çift sürme sahnesi ile oldukça nadir bir kompozisyona sahiptir, üniktir.

Eserin ana sahnesindeki öküzlerin hörgüçlü olmasıyla Hint öküzünün (Zebu veya Zebus) bölgede tanındığı, büyük olasılıkla yetiştirildiği ve ekonomide yer bulduğu anlaşılmaktadır. Bu bağlamda lahit, döneminde bölgedeki bir hayvan çeşidini göstermesi yönünden de önemlidir.

İşlenen konu; Roma Dönemi'ne ait bu tip lahitlerdeki sahnelerde olduğu gibi burada da

yıl önce Teke Yarımadası'ndaki eski kara topografyası, boğulmuş kıyı yapıları ile koy ve körfezlere dönüşmüştür. Bu koy ve körfezlere akarsuların taşıdığı alüvyonlarla deniz dolmaya başlamış, lagünler meydana gelmiş ve sonucunda bataklık olan kıyı ovaları oluşmuştur. Bölgenin evrimine paralel Boğaçay Ovası'nın bulunduğu bölgede son buzul çağı sonrası deniz seviyesinin yükselmesi ile akarsuların getirdiği malzemeler delta şeklinde dolgu oluşturmaya başlamıştır. Bu granuler malzeme dolgusu kıyı oku şeklinde günümüzde limanın bulunduğu bölgeye kadar ilerleyerek kuzeyde kalan körfez parçasını lagüne dönüştürmüştür. Günümüzdeki Sarısu Deresi olasılıkla bu lagünün çıkış ağzı olmalıdır. Bu lagün içindeki sedimantasyon, mikro canlıların yaşamsal faaliyetlerinin yan ürünü olarak ortaya çıkan otojenik kil, taşınmış kil ve siltten oluşan ince taneliler ile taşkın zamanları yamaçlardan ve kuzeyden taşınan granuler malzemedir. Sedimantasyon durduktan sonra Saz Ovası batısı ve Hurma Mahallesi çevresinde yamaç sürüntüsü ve taşkın malzemelerinden oluşan alüvyon yelpazelerin ortasında sulak alan niteliğinde suya doygun zeminler kalmıştır. Bk. Dipova 2010, 74. 
mezar sahibinin zengin bir çiftçi olduğunu gösterir. Imago clipeata içindeki kadın ile erkek, karıkoca olmalıdırlar. Erkek büstünde kıvırcık saçlı genç bir adam görünümü yanında ana sahnedeki çiftçide olasılıkla lahit sahibi aynı kişinin sakallarıyla yaşlı bir görünüm sergilemesi ilginçtir; yaşta farklı zamanları gösterebilir. Yerel üretim lahit üzerindeki figürleri portre açııından kıyaslamak veya değerlendirmek sağ|ıklı olmamakla birlikte, her iki erkeğin aynı kişi olduğu ve dolayısıyla adeta bir yaşam hikâyesinin sergilendiğini belirtmek yanlış olmaz. Yani gençken evlenen bu adam yaşlılığına kadar veya hayatı boyunca çiftçilikle uğraştığına dair bir anlam çıkarılabilir. Bu bağlamda döneminde de tarıma elverişli olduğu anlaşılan bu yerde gerçekten çiftçilikle uğraşan bir erkek bireyin olduğu ve belki çift sürdüğü tarlasının ortasında bulunan kaya kütlesinin vasiyeti gereği işlenerek kendisine lahit mezar olarak yaptırıldığı ve içerisine gömüldüğü olasılığını da düşünmek gerekir. Nitekim yerel kireçtaşı üzerine yerel üretim Hurma Lahdi'nin oldukça sade figürleri düşünüldügünnde, üst düzey iş̧̧ilikli lahitler gibi çok büyük bir işçilik ve masraf gerektirmeyeceğinden, varlıklı bir çiftçinin vasiyeti gereği kendisiyle birlikte eşi için hazırlanmış bir lahit olabilir.

Hurma Lahdi üzerindeki saban sürme sahnesi adandığı şahsın çiftçilikle uğraştığını göstermenin yanı sıra Büyük İskender Dönemi Tarsus sikkeleri üzerinde tıpkı Ba'al Tars gibi betimlenen Zeus'un önünde asma-başak yerine betimlenen saban gibi bolluk ve refaha işaret etmektedir. Sabanın asma-başak ile sembolik birlikteliği göz önüne alındığında ise mezar ikonografisinde dolaylı yoldan da olsa sonsuz yaşam veya öldükten sonra yaşam inancını sembolize ettiği de önerilebilir.

Dar yüzlerinde bulunan kalkan ve mızrak betimlemeleriyle daha çok Pisidia geleneğini yansıtan ve büyük olasılıkla bölgedeki yerel üretim lahitlerdeki stil ve ikonografiye hâkim gezici yerel ustalarca yapılan lahdin konusu, bu tip lahitlerin genel üretim tarihleri, Medusa figürleri ile büstlerin genel durumu, portre açısından sağlıklı bir karşılaştırma yapılamasa da sağ büstteki erkeğin kıvırcıklı saçı ile ana sahnedeki çiftçinin kıvırcıklı saç ve sakal yapısının AntoninlerSeveruslar Dönemi'ni anımsatması; dolayısıyla zaman olarak bu dönemleri geçme olasıllı̆ı ve hızlıca yayılan Hıristiyanlığa ilişkin herhangi bir figürün veya işaretin bulunmayışı gibi etkenler düşünüldüğünde, Hurma Çiftçi Lahdi'ni Roma İmparatorluk Dönemi içerisinde MS III. yüzyıl gibi bir zamana tarihlemek mümkündür. Ayrıca tarihlemeye paralel olarak Lahdin yapıldığı dönemde her ne kadar en azından bu yakın civar tarıma elverişli olsa da lahdin altındaki toprağın killi-çakıllı dokusundan; alanın Roma'dan çok önceki zamanlarda eski bir deniz tabanı olduğu ve dolayısıyla Hurma-Liman civarındaki düzlük arazinin çok uzun bir zaman diliminde dolarak bir ova görünümüne kavuştuğu söylenebilir.

\section{BIBLIYYOGRAFYA}

Abbasoğlu 1987

Akçay - Gürel 2018

Akın - Esgici 2015

Akurgal 1955

Akurgal 1968

Akurgal 1995
H. Abbasoğlu, "1986 Yılı Termessos Yüzey Araştırmaları". V. Araştırma Sonuçları Toplantısı I (1987) 213-230.

A. Akçay - B. Gürel, "Görülenin Ötesine Gitmek: Sayısal Görüntüleme Metotları Işığında Termessos'tan Sütunlu Bir Lahit Üzerine Yeni Değerlendirmeler", Eds. M. Arslan, F. Baz, Arkeoloji, Tarih ve Epigrafi'nin Arasında: Prof. Dr. Vedat Çelgin'in 68. Doğum Günü Onuruna Makaleler. Arkeoloji ve Sanat Yayınları, İstanbul (2018) 1-18.

E. Akın - R. Esgici, "Eski Çağ'da Tarım Aletleri". Tarım Makinaları Bilimi (Journal of Agricultural Machinery Science) 11-1 (2015) 33-37.

E. Akurgal, Phrigische Kunst. Ankara 1955.

E. Akurgal, The Art of Greece: Its Origins in the Mediterranean and Near East. New York 1968.

E. Akurgal, Hatti ve Hitit Uygarlıkları. İzmir 1995. 
Akurgal 1998

Aldrete 2004

Aydoğdu 2016

Bielefeld 1997

Borchhdart 1976

Bülbül 2017

Cambi 2010

Carpenter 2002

CNG Auction 49-1999

CNG Auction 84-2010

CNG Auction 85-2010

CNG Auction 88-2011

Colledge 1982

Çağdaş 1955

Çelgin 1990

Çelgin 1994

Çelik 2017

Çelik et. al. 2018

Çekilmez 2015

Çevik 1996

Çevik et. al. 2005

Delemen 2011

Demircioğlu 1953

Demirer 2013

Dipova 2010

Durugönül 2008

Elsner 2018

Eren 1999

Erdkamp 2005
E. Akurgal, Anadolu Kültür Tarihi. Ankara 1998.

G. S. Aldrete, Daily Life in Roman City: Rome, Pompei, and Ostia. London 2004. M. Aydoğdu, "Roma Hukukunda Toprak Sistemi ve Tarım Reformu Girişimleri". Cevdet Yavuz'a Armağan I-22/3 (2016) 375-382.

D. Bielefeld, Stadtrömische Eroten-Sarkophage: Weinlese und Ernteszenen. Berlin 1997.

J. Borchhdart, Die Bauskulpturs des heroons von Limyra: das Grabmal des lykischen Königs Perikles. Istanbuler Forschungen 32. Berlin 1976.

P. Bülbül, "Eski Anadoluda Tarım Faaliyetleri". Tarihin Peşinde: Uluslararası Tarih ve Sosyal Araştırmalar Dergisi 17 (2017) 269-282.

N. Cambi, Sarkofazi Lokalne Produkcije u Rimskoj Dalmaciji (Die Sarkophage der Lokalen Werkstätten im Römischen Dalmatien). Split 2010.

T. H. Carpenter, Antik Yunan'da Sanat ve Mitoloji. Çev. Bensen B.M. Ünlüoğlu. İstanbul 2002.

Classical Numismatic Group, Inc. CNG Auction 49. Lancester - London 1999.

Classical Numismatic Group, Inc. CNG Auction 84. Lancester - London 2010.

Classical Numismatic Group, Inc. CNG Auction 85. Lancester - London 2010.

Classical Numismatic Group, Inc. CNG Auction 88. Lancester - London 2011.

M. Colledge, Roma Sanatını Tanıyalım. Çev. Solmaz Turunç. İstanbul 1982.

K. Çağdaş, "Hindistan'da İnek Kültü ve Bu Kültün Menşei Üzerine Bir Araştırma". Ankara Üniversitesi Dil ve Tarih-Coğrafya Fakültesi Dergisi 13-1.2 (1955) 53-67.

A. V. Çelgin, Termessos Antik Kenti Nekropol'leri. Yayımlanmamış Doktora Tezi, İstanbul Üniversitesi. İstanbul 1990.

A. V. Çelgin, "Termessos ve Çevresinde Nekropol ve Epigrafya Araştırmaları: 1975-1991 Yılları Arasında Yapılan Çalışmaların Toplu Sonuçlarına Kısa Bir Bakış". Anadolu Araştırmaları XIII (1994) 153-177.

A. Çelik, Beycik 'Fırıncık Mevkii' Antik Yerleşimi: Topografyası, Şehirciliği, Mimarisi. Yayımlanmamış Doktora Tezi, Akdeniz Üniversitesi. Antalya 2017.

A. Çelik - S. Atalay - F. Büyükyörük, "Hisarçandır'dan Ele Geçen Marcus Aurelius Kamoas ve Ailesine Ait Lahit Mezar". Phaselis IV (2018) 181-198. http://dx.doi.org/10.18367/Pha.18012

M. Çekilmez, "2008 Yılı Tralleis Kazısı Koroplastik Buluntuları". Cedrus III (2015) 51-66. DOI: 10.13113/CEDRUS.2015011395

N. Çevik, "Yeni Bulgular Işığında Elmalı Yaylası". Adalya I (1996) 61-72.

N. Çevik - B. Varkıvanç - S. Bulut - I. Kızgut, "V. Roma Dönemi Kalıntıları". Eds. N. Çevik, B. Varkıvanç, E. Akyürek, Trebenna: Tarihi, Arkeolojisi ve Doğası, Adalya Ek Yayın Dizisi 1 (2005) 31-80.

I. Delemen, “Anadolu ve Trakya Topraklarında İz Bırakan İmparatorlar (MÖ 6.MS 4. yüzyıl): İstilacı, Yönetici Tanrı ya da Gezgin". Imparatorlar Istanbul'da: Hitit'ten Osmanlı'ya (2011) 57-124.

H. Demircioğlu, Roma Tarihi 1. Ankara 1953.

Ü. Demirer, Kibyra Metal Buluntuları. Yayımlanmamış Doktora Tezi, Akdeniz Üniversitesi. Antalya 2013.

N. Dipova, “Boğaçay (Antalya) Kıyı Ovası'nın Mühendislik Jeolojisi Değerlendirmeleri”. Jeoloji Mühendisliği Dergisi 34-2 (2010) 71-84.

S. Durugönül, "Silifke Müzesi'nden Bir 'Clipeata Imago'”. Olba XVI (2008) 193206.

J. Elsner, "Ornament, Figure and Mise en Abime in Roman Sarcophagi". Eds. N. Dietrich - M. Squire, Ornament and Figure in Greek and Roman Art (2018) 353-391.

H. Eren, Türk Dilinin Etimolojik Sözlüğü. Ankara 1999.

P. Erdkamp, The Grain Market in the Roman Empire: A Social, Political and Economic Study. Cambridge 2005. 
Erhat 1972

Frel - Morgan 1987

Fuchs 1979

Grimal 1997

Gow 1914

Gusmani 1995

Gürel 2016

Hawkins 2000

Hekler 1912

Herdejürgen 1996

Hrozný 1937

Hoffner 2010

Huskinson 2015

İdil 1981

İnan 1956

Immerwahr 1964

Işık 1982

Işık 1999

Işık 2009

Işık 2012

Işık 2015

Janic 2002

Joolen 2003

Karamut 1991

Kızıltan 2013

Koch 2001

Koch 2010

Koch - Sichterman 1982

Kranz 1984

Kranz 1999

Lanckoroński 1890
A. Erhat, Mitoloji Sözlüğü. İstanbul 1972.

J. Frel - S. K. Morgan, Roman Portraits in the J. Paul Getty Museum. 1987.

W. Fuchs, Die Sculptur der Griechen. München 1979.

P. Grimal, Mitoloji Sözlüğü: Yunan ve Roma. Çev. S. Tamgüç. İstanbul 1979.

A. Gow, "The Ancient Plough". The Journal of Hellenic Studies 34 (1914) 249275.

R. Gusmani, "Zum Stand der Erforschung der lydischen Sprache". Eds. E. Schwertheim, Forschungen in Lydien (1995) 9-19.

B. Gürel, "Phaselis Batı ve Kuzeybatı Nekropolis'leri". MJH VI-2 (2016) 279297. DOI:10.13114/MJH.2016.298

J. D. Hawkins, Corpus of Hieroglyphic Luwian Inscriptions I: Inscriptionsof the Iron Age 3. Berlin - New York 2000.

A. Hekler, Greek \& Roman Portraits. New York 1912.

$\mathrm{H}$. Herdejürgen, Stadrömische und Italische Girlandensarkophage: Die Sarkophage des Ersten und Zweiten Jahrhunderts. Berlin 1996.

B. Hrozný, Les Inscriptions Hittites Hiéroglyphiques: Essai de Déchiffrement, Suivi d'une Grammaire Hittie Hiéroglyphique en paradigmas et d'une liste d'hiéroglyphes 1-3. Praha 1937.

H. A. Hoffner Jr., "Hititler Anadolu'sunda Yasal ve Sosyal Kurumlar". Çev. S. Çilingir. Tarih Okulu VI (2010) 223-244.

J. Huskinson, Roman Strigillated Sarcophagi: Art and Social History. Oxford 2015.

V. İdil, Likya Lahitleri. Doçentlik Tezi, Ankara Üniversitesi. Ankara 1981.

A. İnan, Eski Mısır Tarih ve Medeniyeti. Ankara 1956.

H.R. Immerwahr, Some Inscriptions on Attic Pottery. North Carolina 1964.

F. Işık, "Kleinasiatische Girlandensarkophage mit Pilaster-oder Säulenarchitektur". Jahresheften des Österreichischen Archäologischen Institutes 53 (1982) 30-146.

F. Işık, "Balıkçı'nın Eski Anadolusu". Balıkçı'ya Merhaba: Halikarnas Balıkçısı Günleri. Edebiyatçılar Derneği 16 (1999) 58-78.

F. Işık, "Suya Gömülen "Adsız" Höyükler ve Malidiya/Melid", 2. Uluslararası Melita'dan Battalgazi'ye Tarih-Arkeoloji-Kültür-Sanat Günleri (2009) 23-64.

F. Işık, "Hellen Mucizesi Var Mıydı?". Uygarlık Anadolu'da Doğdu (2012) 175192.

F. Işık, "Arkeolojik Bulgular Işığında Milyas". Anadolu/Anatolia 41 (2015) 187237.

J. Janic, "Ancient Egyptian Agriculture and the Origins Horticulture". Acta Horticulturae 582, ISHS (2002) 23-39.

E. V. Joolen, Archaeological Land Evaluation: A Reconstruction on the Suitability of Ancient Landscapes for Various Land Uses in Italy Focused on the First Millenium BC, Universty of Groningen 2003.

i. Karamut, "Dokimeion Heykelleri". Belleten 55/214 (1991) 605-612.

Z. Kızıltan, "Neolitik Çağ'dan Doğu Roma'ya Anadolu". Anadolu Medeniyetleri: Neolitik Çağ'dan Osmanlı Imparatorluğu'na (2013) 8-28.

G. Koch, Roma Imparatorluk Dönemi Lahitleri. İstanbul 2001.

G. Koch, Türkiye'deki Roma Imparatorluk Dönemi Lahitleri (Sarkophage der römischen Kaiserzeit in der Türkei). Çev. B. Varkıvanç. Antalya 2010.

G. Koch - H. Sichterman, Römische Sarkophage. München 1982.

P. Kranz, Jahreszeiten-Sarkophage: Etwicklung und Ikonographie des Motivs der Vier Jahreszeiten Auf Kaiserzeitlichen Sarkophagen und Sarkophagdeckeln. Berlin 1984.

P. Kranz, Stadtrömische Eroten-Sarkophage: Dionysische Themen, Mit Ausnahme der Weinlese und Ernteszenen. Berlin 1999.

K. G. Lanckoroński, Städte Pamphyliens und Pisidiens. Pamphylien Band I. 
Lanckoroński 1892

Long 2014

McCann 1978

Mithchell 1914

Morley 2010

Muscarella 2013

Musée du Louvre 1985

Neumann 1981

Perego 2017

Perini 1984

Pfhul - Möbius 1979

Poulsen 1974

Rehkugler 2011

Reyhan 2010

Ruperti 1841

Sancaktar 2009

Saydam 2018

Şahan 2009

Şahin 1981

Şanlıbayrak 2013

Şimşek 1998

O'Grady 2015

Özdemir 2016

Özdilek 2006

Özdilek - Çevik 2009
Wien 1890.

K. G. Lanckoroński, Städte Pamphyliens und Pisidiens. Pisidien Band II. Wien 1892.

T. E. Long, Great Grand Mothers. The Female Portrait Sculpture of Aphrodisias: Origins and Meaning. PhD Thesis, University of Nottingham. Nottingham 2014.

A. M. McCann, Roman Sarcophagi in The Metropolitan Museum of Art. New York 1978.

S. Mithchell, "The Trajanic Tondo from Roman Ankara: In Search of the Identity of a Roman Masterpiece". Journal of Ankara Studies 2-1 (2014) 1-10.

N. Morley, "Agriculture, Roman". Eds. M. Gagarin - E. Fantham. The Oxford Encyclopedia of Ancient Greece and Roma (2010) 49-51.

O. W. Muscarella, Archaeology, Artifacts and Antiquities of the Ancient Near East: Sites, Cultures, and Proveniences. London 2013.

Musée du Louvre, Catalogue des Sarcophages En Pierre D'époques Romaine Et Paléochrétienne. Paris 1985.

G. Neumann, "Lateinisch Stiva 'Pflugsterz'”. Würzburger Jahrburger N.F. 7 (1981) 223-227.

R. Perego, Contribution to the development of the Bronze Age plant Economy in the surrounding of the Alps: an archaeobotanical case study of two Early and Middle Bronze Age sites in northern Italy (Lake Garda Region). Erlagung der Würde eines Doktors der Philosophie vorgelegt der, Universität Basel. Basel 2017.

R. Perini, Scavi archaeologici nella zona palafitticola di Flavé-Carera, Parte I, Campagne 1969-1976, Situazione dei depositi e dei resti strutturali. Patrimonio storico e artistico del Trentino 8. Trento 1984.

E. Pfhul - H. Möbius, Die Ostgriechischen Grabreliefs. Mainz am Rhein 1979.

P. V. Poulsen, Les Portraits Romains II: De Vespasian á la Basse-Antiquite. Copenhague 1974.

G. E. Rehkugler, The Rau Model Plow Collection at Cornell Universtiy and The Evolution of Plow Design. Ithaca - New York 2011.

E. Reyhan, "Hititlerde Gündelik Hayata Dair İktisadi İlişkiler". Tarih Araştırmaları Dergisi 47 (2010) 65-82.

G. F. F. Ruperti, Handbuch der Römischen Alterthüme. Hannover 1841.

H. Sancaktar, Anadolu'daki Roma Koloni Kentleri ve Sikke Tipolojisi. Yayımlanmamış Yüksek Lisans Tezi, Ankara Üniversitesi. Ankara 2009.

T. Saydam, "Roma Cumhuriyeti'nde Kölelik: Spartaküs Örneği". Journal of Social Sciences and Humanities 1-2 (2018) 76-90.

M. M. Şahan, Batı Anadolu'da Podyum Mimarisinin Oluşumu. Yayımlanmamış Yüksek Lisans Tezi, Dokuz Eylül Üniversitesi. İzmir 2009.

S. Şahin, Katalog der antiken Inschriften des Museums von Iznik (Nikaia): entfernte Umgebung der Stadt II-I. Bonn 1981.

H. Şanlıbayrak, Erken Ortaçağ'da Avrupa'da Kölelik: III. ve IV. Yüzyıllar Arasında Avrupa'da Kölelik. 2013.

C. Şimşek, "Laodikya Ana Küme Girlandlı Lahitleri". Arkeoloji ve Sanat 85 (1998) 2-25.

S. A. O'Grady, The Public Image of the Later Severans: Caracalla to Alexander Severus. Degree of Master Ths. The Universty of Queensland. Queensland 2015.

B. Ş. Özdemir, Tlos Tanrı ve Kültleri. Yayımlanmamış Doktora Tezi, Akdeniz Üniversitesi. Antalya 2016.

B. Özdilek, Neapolis Nekropolü. Yayımlanmamış Yüksek Lisans Tezi, Akdeniz Üniversitesi. Antalya 2006.

B. Özdilek - N. Çevik, New Discoveries in Rural North East Lycia: Scenes of 
Özdoğan 2007

Özer 2014

Özgan 2013

Özüdoğru 2014

Öztürk 2003

Tiryaki 2001-2002

Tiryaki 2013

Paul Getty Museum 1990

Triton XIII-2010

Triton XVI-2013

Triton XVII-2014

Triton XVIII-2015

Triton XIX-2016

Triton XX-2017

Triton XXI-2018

Tokat 2014

Turgut 2017

Tüner Önen 2008

Tüner Önen et. al. 2017

Varro, De Lingua Latina V Vermeule 1981

Waelkens 1982

White 1967

White 1970
Daily Life on Roman Rural Sarcophagi". Soma 2007, BAR (2009) 284-290.

M. Özdoğan, "Neolitik Dönem: Günümüz Uygarlığının Temel Taşları". 12000 Yıl Önce "Uygarlığın Anadolu'dan Avrupa'ya Yolculuğunun Başlangıcı" Neolitik Dönem. (2007) 9-20.

E. Özer, "A Typological Suggestion Concerning Hellenistic and Roman Lycian Sarcophagi". Cedrus II (2014) 75-87. DOI: 10.13113/CEDRUS.201406455

R. Özgan, Roma Portre Sanatı II. İstanbul 2013.

Ş. Özüdoğru, "Kibyra'dan Hellenistik Döneme Ait Yeni Veriler Üzerine Değerlendirmeler". Cedrus II (2014) 171-188. DOI: 10.13113/CEDRUS.201406458

A. Öztürk, Batı Dağlık Kilikya Bölgesi Kaya Mezarları. Yayımlanmamış Yüksek Lisans Tezi, Pamukkale Üniversitesi. Denizli 2003.

G. Tiryaki, “ivriz Kabartması Işığında Anadolu'da Şarap-Tanrı Anlayışı ve Bu Anlayışın Gelişimi Üzerine". Adalya V (2001-2002) 59-71.

G. Tiryaki, "Yeni Hitit Sanatı Üzerine İkonografik Araştırmalar (1): Üzüm Salkımı ve/veya Başak Filiz Taşıyanlar". Cedrus I (2013) 33-53. DOI: 10.13113/CEDRUS/20131673

The J. Paul Getty Museum, Roman Funerary Monuments: In The J. Paul Getty Museum I. Malibu 1990.

Triton XIX: In Conjunction with the 38th Annual New York International Numismatic Convention. New York 2010.

Triton XVII: In Conjunction with the $41^{\text {st }}$ Annual New York International Numismatic Convention. New York 2013.

Triton XVII: In Conjunction with the $42^{\text {nd }}$ Annual New York International Numismatic Convention. New York 2014.

Triton XVIII: In Conjunction with the $43^{\text {rd }}$ Annual New York International Numismatic Convention. New York 2015.

Triton XIX: In Conjunction with the $44^{\text {th }}$ Annual New York International Numismatic Convention. New York 2016.

Triton XIX: In Conjunction with the $45^{\text {th }}$ Annual New York International Numismatic Convention. New York 2017.

Triton XIX: In Conjunction with the $46^{\text {th }}$ Annual New York International Numismatic Convention. New York 2018.

F. Tokat, "Çavdır Ağzından Derleme Sözlüğü’ne Katkılar". Uluslararası Türkçe Edebiyat Kültür Eğitim Dergisi (International Journal of Turkish Literature Culture Education) 3/1 (2014) 153-166.

M. Turgut. "Dress and Culture in the Hittite Empire and during the Late Hittite Period according to Rock Reliefs". Eds. G. Motta - A. Biagini, Fashion Through History: Costumes, Symbols, Communication I (2017) 2-13.

N. Tüner Önen, Phaselis Antik Kenti ve Teritoryumu. Yayınlanmamış Doktora Tezi, Akdeniz Üniversitesi. Antalya 2008.

N. Tüner Önen - B. Gürel - A. Akçay, "Phaselis Teritoryumunda Tespit Edilen Lahitlerin RTI Metodu Işığında Arkeolojik ve Epigrafik İncelemeleri". Phaselis III (2017) 343-369. DOI: 10.18367/Pha.17021

Varro, On the Latin Language. Çev. R. G. Kent. Cambridge 1938.

C. C. Vermeule, Greek and Roman Sculpture in America. Los Angeles - London (1981)

M. Waelkens, Dokimeion: Die Werkstatt Der Repräsentativen Kleinasiatischen Sarcophage, Chronologie und Typhologie Ihrer Produktion II. Berlin 1982.

K. D. White, Agricultural Implements of the Roman World. Cambridge 1967.

K. D. White, Roman Farming: Aspects of Greek and Roman Life. London and Southampton 1970. 